\title{
ZUSGS
}

\section{Preliminary Report on Mercury Geochemistry of Placer Gold Dredge Tailings, Sediments, Bedrock, and Waters in the Clear Creek Restoration Area, Shasta County, California}

By Roger P. Ashley, ${ }_{1}^{1}$ James J. Rytuba, ${ }_{1}$ Ronald Rogers, ${ }^{2}$ Boris B. Kotlyar, ${ }^{1}$ and David Lawler ${ }^{3}$

Open-File Report 02-401

2002

This report is preliminary and has not been reviewed for conformity with U.S. Geological Survey editorial standards or with the North American Stratigraphic Code. Any use of trade, firm, or product names is for descriptive purposes only and does not imply endorsement by the U.S.

Government.

U.S. DEPARTMENT OF THE INTERIOR

U.S. GEOLOGICAL SURVEY

${ }^{1}$ U.S. Geological Survey, Menlo Park, California.

${ }^{2}$ U.S. Bureau of Land Management, Redding, California.

${ }^{3}$ U.S. Bureau of Land Management, Sacramento, California. 


\section{TABLE OF CONTENTS}

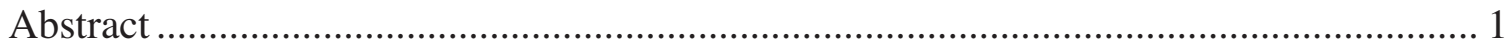

Introduction

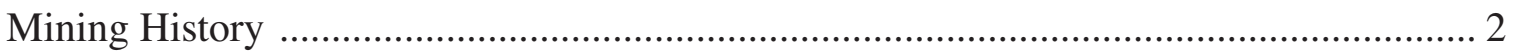

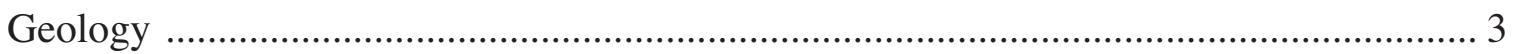

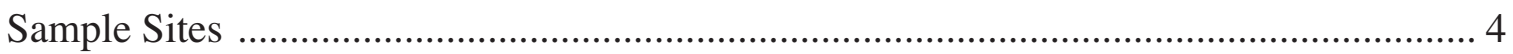

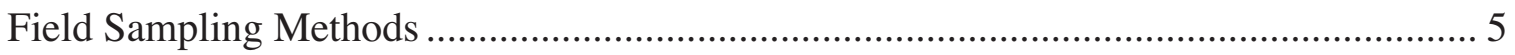

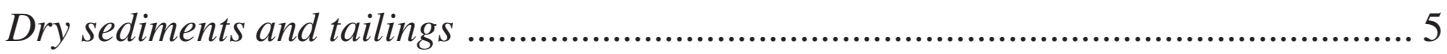

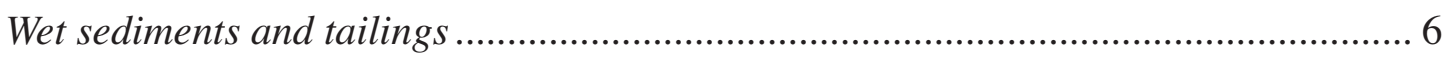

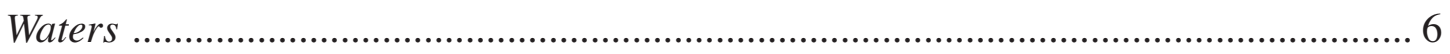

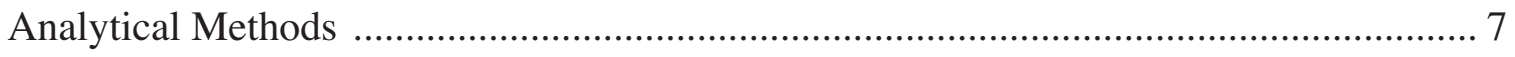

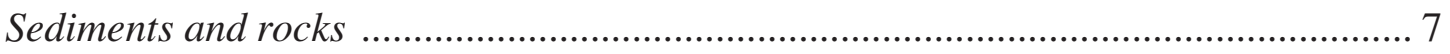

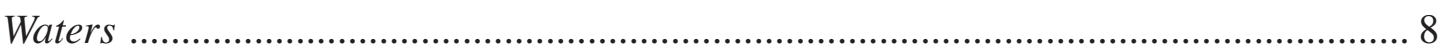

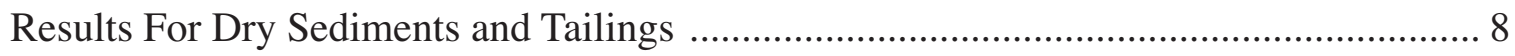

Results For Wet Sediments and Tailings .......................................................... 9

Effect of Sample Treatment on Analytical Results, and Implications ............................ 10

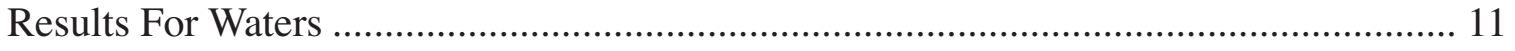

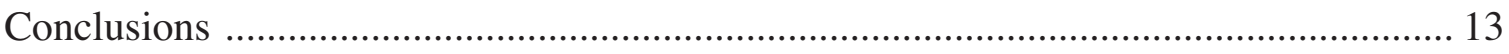

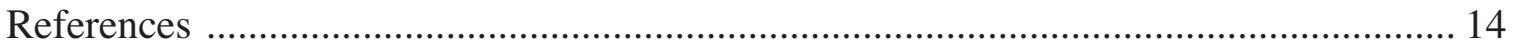




\section{TABLES}

1-Locations and descriptions of sample sites in and near the Clear Creek Restoration Project area

2-Comparison of preparation and analytical procedures used for solid samples by ALS Chemex and Frontier Geosciences laboratories

3-Mercury and methylmercury concentrations in dredge tailings and sediment samples

4-Concentrations of major and minor elements in dredge tailings and sediment samples, determined by ICP-MS and ICP-AES

5-Field parameters for water sample sites and concentrations of major anions, mercury, and methylmercury in waters

6-Concentrations of major and minor cations in waters, determined by ICP-MS and ICPAES

\section{ILLUSTRATIONS}

1-Locations of samples in the Clear Creek study area

2-South Pond, on the flood plain of Clear Creek, showing clouds of fine sediment from local tailings used to fill the pond

3-East Pond, a marshy pond occupying an abandoned channel (meander scar) on the flood plain of Clear Creek

4-Pond 3, a shallow pond occupying a meander scar on the flood plain of Clear Creek

5-Dragline dredge stacker tailings, Spring Creek

6-Dredge sluice tailings (sand, silt, and clay), overlain by stacker tailings (pebbles and cobbles), exposed in wall of Schmidt Pit, Shooting Gallery area. Bulk mercury concentrations in the various tailings layers are shown

7-Red Pond, an abandoned dredge pond fed by high-chloride springs

8-Conglomerate of the Tehama Formation, exposed in prospect tunnels beneath the Nomlaki Tuff, at Red Pond

9-Mercury concentrations in bedrock, unmined conglomerate, dredge stacker tailings, and dredge sluice tailings, as a function of grain size

10-Mercury concentrations in sediments from ponds, hydraulic mine drainage tunnel, and Clear Creek

11-Methylmercury concentrations in sediments from ponds, hydraulic mine drainage tunnel, and Clear Creek

12-Comparison of total mercury concentrations in sediments and tailings determined by two different methods (ALS Chemex method and Frontier Geosciences method) 
13-Mercury concentrations in waters, showing amounts of dissolved and suspended mercury

14-Methylmercury versus total mercury concentrations in waters

15-Sulfate versus total mercury concentrations in waters

16-Iron versus total mercury concentrations in waters

17-Chloride versus total mercury concentrations in waters

18-Chloride versus lithium and boron concentrations in waters 


\begin{abstract}
Clear Creek, one of the major tributaries of the upper Sacramento River, drains the eastern Trinity Mountains. Alluvial plain and terrace gravels of lower Clear Creek, at the northwest edge of the Sacramento Valley, contain placer gold that has been mined since the Gold Rush by various methods including dredging. In addition, from the 1950 s to the 1980s aggregate-mining operations removed gravel from the lower Clear Creek flood plain.
\end{abstract}

Since Clear Creek is an important stream for salmon production, a habitat restoration program is underway to repair damage from mining and improve conditions for spawning. This program includes using dredge tailings to fill in gravel pits in the flood plain, raising the concern that mercury lost to these tailings in the gold recovery process may be released and become available to biota. The purposes of our study are to determine concentrations and speciation of mercury in sediments, tailings, and water in the lower Clear Creek area, and to determine its mobility.

Mercury concentrations in bedrock and unmined gravels both within and above the mined area are low, and are taken to represent background concentrations. Bulk mercury values in flood-plain sediments and dry tailings are elevated to several times these background concentrations. Mercury in sediments and tailings is associated with fine size fractions. Although methylmercury levels are generally low in sediments, shallow ponds in the flood plain may have above-normal methylation potential.

Stream waters in the area show low mercury and methylmercury levels. Ponds with elevated methylmercury in sediments have more methylmercury in their waters as well. One seep in the area is highly saline, and enriched in mercury, lithium, and boron, similar to connate waters that are expelled along thrust faults to the south on the west side of the Sacramento Valley. This occurrence suggests that mercury in waters may at least in part be from sources other than placer mining.

\title{
Introduction
}

The Klamath Mountains of northern California and southwestern Oregon have produced significant amounts of gold, both from placer and lode deposits. The most important placer deposits occur along the major rivers, including Clear Creek and the Trinity, Klamath, and Smith Rivers, and their tributaries (Clark, 1970). The placers of lower Clear Creek, which are the subject of this report, have been mined intermittently by various methods since the 1850s (Clark, 1970; Averill, 1933), with the result that all the alluvial gravel forming the flood plain of Clear Creek and most of the gravel capping adjacent terraces has been disturbed. In addition, in recent decades gravel has been removed from the lower Clear Creek alluvial system for aggregate. 
Through most of the placer mining period, mercury was used for recovery of gold by amalgamation, resulting in contamination of the sediment that was processed. Elevated levels of mercury have been recognized as a water quality problem throughout the Sacramento River basin (Domagalski, 1998; Domagalski and others, 2000). Sources of this mercury include mercury mines in the Coast Ranges and mercury losses from gold mining operations, both placer and lode, in the Klamath Mountains and Sierra Nevada.

Habitat restoration for migratory salmon has been underway in the lower Clear Creek basin since 1998. Mercury contents of the sediments impounded behind Saeltzer Dam, in the upper part of the lower Clear Creek basin, were examined as part of a floodway rehabilitation project involving removal of the dam (Yahnke, 2001). Sediments that have been exposed to mercury have been used for flood plain restoration, and may be used in the future. The purpose of this study is to determine how much mercury has been added to the sediments, how it is distributed within them, how it may be released, and whether unusual amounts of methylmercury are associated with sediments under any conditions. In addition we have looked at mercury and methylmercury concentrations in springs, ponds, and Clear Creek itself within and above the restoration area, to determine whether significant amounts of mercury are being leached from sediments into waters, and whether there are conditions permitting high rates of methylation. A study of mercury levels in biota is being carried out concurrently to determine whether amounts of methylmercury greater than background levels are entering the food chain in the area.

\section{Mining History}

Following the initial discovery of gold in gravels of the Trinity River in 1848, placer deposits were the main source of gold in the region until the 1880s (Clark, 1970). Gold was discovered in Clear Creek in 1849. Several mining camps were established in the lower Clear Creek drainage basin, including Whiskeytown, Horsetown, Shasta, and Igo. For the first few years, crude methods were used to mine the gravels in the active channel and adjacent flood plain; mercury was not available for gold recovery.

In the mid-1850s hydraulic mining was developed. In this mining method, hydraulic monitors were used to excavate off-stream gravels, especially in paleochannels or on benches. Extensive systems of sluices charged with mercury were used to recover the gold. Hydraulic mining of the terrace deposits in the lower Clear Creek area likely took place mainly before 1884, at which time most hydraulic mining in tributaries of the Sacramento and San Joaquin Rivers was shut down by judicial decree (Sawyer Decision).

From the 1880s until World War I, lode and placer mines produced roughly equal amounts of gold in the Klamath Mountains. Gold production declined in the 1920s, but revived in the 1930s as many dredges were put in operation, returning placer deposits to prominence. The placer deposits of lower Clear Creek supported numerous dredging 
operations (Averill, 1933). Large areas in the lower Clear Creek valley and some tributary drainages were dredged during this period, using both drag-line and bucket-line dredges. Most mining operations were forced to close in 1942 in response to War Production Board Order L-208, and few were able to reopen after World War II.

Bedrock in the area hosts some narrow and shallow gold-quartz veins that yielded small but rich pockets. The most productive of these was the Yankee John mine, located about $3 \mathrm{~km}$ north of the center of the study area. The French Gulch district, the largest lode gold district in the Klamath Mountains, lies in the Clear Creek drainage basin north of Whiskeytown, above the main placer-mining areas.

Aggregate mining began in the lower Clear Creek basin in the 1950s. Gravel has been obtained both from in-stream and off-stream pits. Mining in-stream and in the adjacent flood plain ceased in the 1980s, but off-stream mining continues.

\section{Geology}

The Klamath Mountains in northern California consist of a series of northwest- to northtrending terranes, or belts of deformed and metamorphosed sedimentary and volcanic rocks ranging in age from Ordovician to Jurassic (Irwin, 1972, 1981). These belts represent a stack of east-dipping thrust plates; from east to west the belts comprise progressively younger rocks. The thrust-fault zones that bound the plates contain ultramafic bodies that are mostly serpentinized. Numerous granitic plutons ranging in age from Devonian through Cretaceous intrude the terranes. Groups of plutons of similar age form belts that parallel the trends of their host rocks (Irwin, 1985).

The Clear Creek drainage basin lies entirely within the Eastern Klamath Terrane, the easternmost and oldest of the belts recognized in the Klamath Mountains. The upper part of the basin, in the French Gulch area and northward, is dominated by slates of the Bragdon Formation of Mississippian age. The lower part of the basin is underlain by metavolcanic rocks of Devonian or older age, including the Copley Greenstone and the Balaklala Rhyolite, and granitic rocks including the Mule Mountain stock of Devonian age, and the Shasta Bally batholith of Early Cretaceous age (Strand, 1962; Albers, 1964; Kinkel, Hall, and Albers, 1956; Fraticelli and others, 1987).

The oldest rocks in the Great Valley province are nearly unmetamorphosed Late Jurassic and Cretaceous marine sedimentary rocks of the Great Valley sequence, which crops out along the west side of the Sacramento Valley. Lithologies include mudstone, graywacke, conglomerate, and shale. There are small exposure areas of both Lower and Upper Cretaceous on the north side of Clear Creek (Strand, 1962).

Formations of Tertiary and Quaternary age occupy most of the area of the Great Valley province, including lower Clear Creek. Tertiary rocks in the lower Clear Creek area are 
included in the Tehama Formation of Pliocene age (Helley and Harwood, 1986). It consists of sandstone and siltstone with lenses of conglomerate derived from the Coast Ranges and Klamath Mountains to the west and north. The Tehama grades eastward into the Tuscan Formation, which consists of volcanic and volcaniclastic rocks erupted and transported from volcanic vents in the Cascades volcanic province to the east.

The Nomlaki Tuff Member of the Tehama Formation is locally exposed in the bluffs and gulches incised into the terrace on the north side of Clear Creek. Some of the best exposures are in drainage cuts and tunnels related to hydraulic mining. The Nomlaki is a dacitic ash-flow tuff, water-reworked in some areas (Helley and Harwood, 1986). In the vicinity of lower Clear Creek it is typically a white or pale gray massive, non-welded pumice lapilli tuff. Its stratigraphic position is at or near the base of the Tehama Formation, and it has been dated at 3.4 Ma (Evernden and others, 1964).

The Tehama Formation is overlain unconformably by the Red Bluff Formation of Quaternary age, which forms a thin veneer of red, weathered gravels. Helley and Harwood (1986) interpret the Red Bluff as a sedimentary cover on a widespread pediment surface that formed in the Sacramento Valley between $450 \mathrm{Ka}$ and about 1.08 Ma. It occupies the broad flat divide between lower Clear Creek and Dry Creek to the south, and scattered patches remain on the north side of Clear Creek. It probably covered the terrace on the north side of Clear Creek that was extensively mined by hydraulic methods.

The flood plain of Clear Creek, including low terraces adjacent to the active stream channel, is underlain by alluvium of Holocene age. The bulk of this material is probably gravel and sand. As a result of restricted sediment supply in the current hydrologic regime, at many places the stream has eroded down to a hard-pan clay layer.

\section{Sample Sites}

Samples were collected to characterize mercury species and associated elements in gold placer tailings, bedrock, sediments, and stream and pond waters in and adjacent to the Clear Creek restoration area. Samples were collected from August 27 to 29, 2001, during late summer base stream-flow conditions. During the time of sampling, the weather was stable and no precipitation occurred. Field sites are shown on Figure 1 and listed and described in Table 1 along with all samples collected at each site. The geographic coordinates in Table 1 were obtained in the field using a hand-held Global Positioning System (GPS) unit.

Field samples are clustered in four parts of the area (Figure 1 and Table 1). The eastern group of samples $(21 \mathrm{CC} 1,2,3,4,5,6,7)$ includes sediments and waters from three ponds in the floodplain. South Pond (Figure 2), the largest of the three, was an aggregate pit. The other two, designated East Pond (Figure 3) and Pond 3 (Figure 4), probably represent 
remnants of abandoned channels. South Pond and Pond 3 were filled in summer 2001 as part of the restoration program.

The next group of samples to the west $(21 \mathrm{CC} 8,9,10,11)$ include hydraulic mine tailings, water and tailings from a hydraulic mine drainage tunnel, and the Nomlaki tuff, which forms the substrate beneath the gravels that were mined by hydraulic methods. In addition, sediments and water from Clear Creek were sampled; this site is immediately above the restoration project area, but still within the reach that was mined.

The cluster of samples toward the west end of the area $(21 \mathrm{CC} 12,13,14,15,16)$ comprises mainly tailings. One site yielded gravel from drag-line dredge stacker piles along Spring Creek, an intermittent tributary of Clear Creek (Figure 5). The second site yielded gravel from probable bucket-line dredge stacker piles on a low Clear Creek terrace. The third site is a backhoe trench dug in probable bucket-line dredge tailings on the same low terrace, both coarse stacker tailings and fine sluice tailings, at the site of a former rifle range known as the "Shooting Gallery" (Figure 6). Also in the Spring Creek drainage is an impoundment remaining from dredging known as "Red Pond" (Figure 7), which catches water from saline springs. Adjacent to Red Pond are exposures of Tehama Formation gravels beneath the Nomlaki Tuff that contain prospect and short drift mine tunnels (Figure 8). We sampled Red Pond water and sediment, and unmined gravel from a drift tunnel.

The westernmost samples $(21 \mathrm{CC} 18,19)$ are located at the U.S. Geological Survey stream gauging station known as the "Igo Gauge." This site provided water and sediment upstream from the mined area.

\section{Field Sampling Methods}

\section{Dry sediments and tailings}

We separated material coarser than $2 \mathrm{~mm}$ (the lower size limit for gravel in the standard Wentworth size classification scheme) from material finer than $2 \mathrm{~mm}$ (the upper size limit for sand in the Wentworth scheme), using a steel wire-mesh screen. We did not attempt to separate any finer fractions in the field, because dry sieving done by hand is ineffective in removing fines from coarser particles. Also we did not homogenize and split bulk material to provide all subsamples; we screened approximately $5 \mathrm{~kg}$ of material dug from a shallow hole or cut from trench walls at each site. Separate grab samples dug from the same holes or cuts supplied material for the bulk subsamples.

All dry tailings subsamples were placed in pre-cleaned and certified borosilicate glass jars with Teflon ${ }^{\mathrm{TM}}$ seals (I-CHEM ${ }^{\mathrm{TM}}$ Series 300$)$. The maximum amount of material retained for any subsample was generally $1-2 \mathrm{~kg}$. 


\section{$\underline{\text { Wet sediments and tailings }}$}

Wet sediments and tailings were wet-sieved in the field using stainless steel sieves and 12 liters of ambient water. The sieves used are dedicated to handling of materials expected to have low levels of mercury and other metals; however, we have not run blanks to determine whether these sieves contribute significant amounts of metals to samples. Although several size fractions were obtained at some sites, those analyzed and reported here are $>2 \mathrm{~mm},<2 \mathrm{~mm},<63 \mu \mathrm{m}$, and unsieved bulk.

Certified Teflon ${ }^{\mathrm{TM}}$-sealed I-CHEM ${ }^{\mathrm{TM}}$ glass jars (the same as for dry sediments) were used for subsamples analyzed for metals. Polycarbonate jars (100 ml capacity) were used for mercury subsamples. These were frozen with dry ice immediately after collection (freezing time approximately 20-30 minutes), and kept frozen until analysis.

\section{$\underline{\text { Waters }}$}

Spring and stream waters were grab samples collected in 1-liter HDPE bottles; all subsamples for analysis of metals and anions were removed from the same 1-liter bottle.

Water sampling protocols used here, including bottle preparation and sample preservation, generally follow those of Water Resources Division of the U.S. Geological Survey for trace metals (Horowitz and others, 1994). Field filtrations were generally done with disposable $25 \mathrm{~mm}$-diameter sterile cellulose acetate filters $(0.45 \mu \mathrm{m}$ openings $)$ and disposable syringes.

For metals determinations, both filtered and unfiltered subsamples were preserved with Ultrex-grade $\mathrm{HNO}_{3}$, acidified to $\mathrm{pH}<2$, and stored in HDPE (high-density polyethylene) bottles pre-rinsed with similar trace-metals grade acid. Subsamples for anion determinations were filtered, stored in HDPE bottles, and chilled to $<4^{\circ} \mathrm{C}$ until analysis. Subsamples for alkalinity determinations were treated similarly but were not filtered.

Sampling for mercury analysis followed ultra-clean sampling and handling protocols (Bloom, 1995, Gill and Fitzgerald, 1987) during the collection of field samples and analysis to avoid introduction of mercury. Subsamples for mercury analysis were separate grab samples collected in 1-liter borosilicate bottles (I-CHEM ${ }^{\mathrm{TM}}$ Series 300 , spot-checked for mercury levels by Frontier Geosciences) with excluding Teflon ${ }^{\mathrm{TM}}$ caps (to eliminate head space), and kept chilled to $<4^{\circ} \mathrm{C}$ until analysis.

During every sampling event, a field blank was collected by processing de-ionized water and collecting the same subsamples (except for alkalinity) by the same procedures as used for the field samples. 
Water parameters including $\mathrm{pH}$, conductivity, and temperature were measured in the field with a battery-powered $\mathrm{pH}$ meter (Orion Model 290, with low-maintenance sealed gel triode electrode) and a specific conductivity meter (Orion Model 120). The $\mathrm{pH}$ triode, which has automatic temperature compensation, was also used for temperature measurements. Dissolved oxygen concentrations were determined with a CHEMets ${ }^{\circledR}$ colorimetric field test kit (CHEMetrics, Inc.).

Laboratory blanks and acid blanks were processed periodically to determine whether our equipment, containers, reagents, and procedures introduced significant contamination.

\section{Analytical Methods}

\section{$\underline{\text { Sediments and rocks }}$}

Multi-element analyses for all dry sediments and rocks were performed in the laboratories of ALS Chemex. Bulk samples were ground in a zirconia ring mill and subjected to a near-total four-acid digestion. Major elements were determined by inductively coupled plasma-atomic absorption spectroscopy (ICP-AES). Minor elements other than mercury were determined by inductively coupled plasma-mass spectrometry (ICP-MS). Mercury was determined by cold vapor atomic absorption spectroscopy (CVAAS) following methods similar to those described by Crock (1996) and O'Leary and others (1996).

Mercury and methylmercury analyses for all wet sediments were carried out at Frontier Geosciences. Some dry sediments analyzed by Chemex were also analyzed by Frontier. For total mercury, the sediment was leached with cold aqua regia, followed by stannous chloride $\left(\mathrm{SnCl}_{2}\right)$ reduction, two-stage gold amalgamation, and cold vapor atomic fluorescence spectroscopy (CVAFS) detection. Methylmercury was obtained by acid bromide/methyl chloride extraction followed by aqueous phase ethylation, isothermal gas chromatographic (GC) separation, and CVAFS detection (Horvat, Bloom, and Liang, 1993). Results were reported on both a wet- and dry-weight basis.

Chemex and Frontier sample preparation steps are shown for comparison in Table 2. Chemex preparation utilizes a relatively large split, which is pulverized. The Chemex 4acid digestion dissolves all but a few resistant minerals such as zircon. It is important to note that our samples were treated as rocks rather than soils, except that crushing was not needed, so no sieving was performed in the laboratory; bulk sample including clasts as large as 1-2 cm diameter was processed. Frontier's preparation avoids handling and uses a strong leach (aqua regia), which removes elemental mercury, adsorbed mercury, mercury in amalgams, and combined mercury including mercury sulfide, but does not affect silicate minerals. Material coarser than sand size, however, is not included in Frontier's leach. 


\section{$\underline{\text { Waters }}$}

Alkalinity as $\mathrm{CaCO}_{3}$ was determined in the laboratory by titration with $\mathrm{H}_{2} \mathrm{SO}_{4}$ using Gran's technique (Orion Research, Inc., 1978), within 2-4 days after sample collection. Sulfate, chloride, nitrate, and fluoride concentrations were determined by ion chromatography (Fishman and Pyen, 1979).

Cations were analyzed by inductively coupled plasma-atomic emission spectrometry (ICP-AES) and inductively coupled plasma-mass spectrometry (ICP-MS). Ion chromatography and alkalinity analyses were performed by U.S.G.S. laboratories under the direction of Paul Lamothe. The ICP-AES analyses were determined by U.S.G.S. laboratories under the direction of Paul Briggs. Duplicate water samples, blank samples, and U.S.G.S. Water Resource Division standard reference waters were analyzed with the data set.

At Frontier Geosciences samples were handled in a Class-100 clean air station monitored routinely for low levels of total gaseous mercury. An ultra-clean mercury trace metal protocol was followed, including the use of rigorously cleaned and tested Teflon ${ }^{\mathrm{TM}}$ equipment and sample bottles and pre-screened and purified reagents. Laboratory atmosphere and water supply are also routinely monitored for low levels of mercury. Primary standards used in the laboratory were NIST-certified or traceable to NISTcertified materials. Monomethylmercury (MMHg) standards were made from pure powder and calibrated against NBS-3133, and cross verified by daily analysis of Certified Reference Material DORM-2 (National Research Council of Canada Institute for National Measurement Standards, 1999). EPA Method 1631 was used. Total mercury was determined by bromine monochloride $(\mathrm{BrCl})$ oxidation followed by $\mathrm{SnCl}_{2}$ reduction, two-stage gold amalgamation, and detection by cold vapor atomic fluorescence spectroscopy (CVAFS) (Bloom, Crecelius, and Fitzgerald, 1988). Methylmercury was liberated from water using an all-Teflon ${ }^{\mathrm{TM}}$ distillation system. Distilled samples were analyzed using aqueous phase ethylation with purging onto Carbotrap, isothermal gas chromatographic (GC) separation, and CVAFS detection (Bloom, 1989). To address accuracy and precision, quality assurance measures were employed with the following minimum frequency: laboratory duplicates, one per ten samples; method blanks, three per analytical batch; filtration blanks, one per ten samples; and spike recovery or standard reference material, one per ten samples.

\section{Results For Dry Sediments and Tailings}

Figure 9 shows results for dry tailings, sediments, and bedrock samples; analytical data are shown in Tables 3 and 4 . The bedrock category consists of pebble composites for metamorphic rocks and plutonic rocks (6-10 pebbles each) and Nomlaki Tuff from an exposure in a hydraulic mine drainage cut. The pebbles came from the gravel being used at the time of sampling to fill South Pond, which was from the flood plain in the vicinity 
of that pond. Metamorphic rock types dominate the Clear Creek sediments. Granitic rock clasts are common but subordinate to metamorphic types. These materials all show relatively low mercury values $(10-30 \mathrm{ng} / \mathrm{g})$. All subsamples of unmined gravel from the Tehama Formation ( $>2 \mathrm{~mm},<2 \mathrm{~mm}$, and bulk) did not have detectable levels of mercury, at a $10 \mathrm{ng} / \mathrm{g}$ threshold. These limited data suggest that background mercury values in the area are relatively low, and a background range of $<10-30 \mathrm{ng} / \mathrm{g}$ is assumed here for comparison purposes.

The remaining categories in Figure 9 represent results for dredge stacker tailings in the Spring Creek area, tailings at the Shooting Gallery, and hydraulic tailings at the hydraulic mine drainage cut. The Clear Creek gravel reported here is from a gravel bar adjacent to the active channel. At all sites where bulk material was analyzed, it is enriched in mercury relative to probable background values, but values for the $>2 \mathrm{~mm}$ fraction are lower than the bulk values. In several cases the $<2 \mathrm{~mm}$ fraction is higher than the bulk value, as expected from the relatively lower values for the $>2 \mathrm{~mm}$ fractions, but the two Spring Creek sites show lower values for the $<2 \mathrm{~mm}$ fraction than for bulk material. Either sampling or analytical error or both may account for this apparently anomalous relationship between values for bulk versus coarse and fine fractions.

Figure 6 shows in more detail the relationship between mercury concentrations and grain size. The photo shows part of the wall of the backhoe trench sampled at the Shooting Gallery site. Here the coarse tailings at the top of the section are very poorly sorted, and mercury is clearly enriched in the $<2 \mathrm{~mm}$ fraction, which includes sand, silt, and clay (values for the fractions from this layer are those shown in Figure 9). The layer below contains the finest material in the section (silt-clay), which shows the highest mercury value $(160 \mathrm{ng} / \mathrm{g})$, whereas sand interbedded with and underlying the silt-clay shows an intermediate value of $90 \mathrm{ng} / \mathrm{g}$. Bulk values for the $>2 \mathrm{~mm}$ portion of the coarse upper layer approach background (40 $\mathrm{ng} / \mathrm{g})$.

Various criteria have been proposed for evaluating mercury levels in bulk sediments (U.S. Environmental Protection Agency, 1997). The lowest of these is the U.S. EPA Threshold Effects Level (TEL), at $130 \mathrm{ng} / \mathrm{g}$. This is a proposed lower limit for effects on biota, above which there is potential for observable effects such as bioaccumulation and biomagnification. Only the fine sediment fractions at the Shooting Gallery site exceed this level.

Methylmercury values for dry tailings and sediments are all very low, ranging from $<0.015 \mathrm{ng} / \mathrm{g}$ to $0.387 \mathrm{ng} / \mathrm{g}$, indicating that no extraordinary conditions favorable for methylation of mercury occur in these materials in the area.

\section{Results For Wet Sediments and Tailings}

Figure 10 shows results for wet sediments and tailings. Mercury values for bulk material from the South Pond exceed any bulk values obtained for dry tailings. This material was 
local tailings being used at the time of sampling to fill the South Pond. Bulk sediments from the other two ponds, which were still undisturbed at the time of sampling, are slightly elevated but close to background levels. Sediment from the mouth of the hydraulic mine drainage tunnel, which probably represents hydraulic tailings, is also clearly enriched in mercury. Bulk sediment from the active channel of Clear Creek west of the restoration project area showed a mercury concentration similar to those in South Pond and the hydraulic drainage tunnel, whereas mercury in Clear Creek sediment at the Igo Gauge is at background levels.

At all sites where silt-clay size material $(<63 \mu \mathrm{m})$ was separated and analyzed, it shows substantially higher mercury concentrations than bulk material, regardless of the bulk mercury concentration. Mud from Red Pond, which is similarly fine-grained, has a mercury level similar to fine-grained material at other sites. Bulk mercury values are generally below the EPA TEL of $130 \mathrm{ng} / \mathrm{g}$, whereas fine fractions all exceed it.

Figure 11 shows results of methylmercury analyses for the same sites and subsamples as shown in Figure 10. Methylmercury generally shows the same tendency to be enriched in the fine fraction relative to bulk material. With the exception of Red Pond, methylmercury generally accounts for about one percent of total mercury present, which indicates normal rates of conversion of mercury to methylmercury. Conditions in Red Pond, however, apparently strongly favor methylation processes.

We have not attempted to evaluate atmospheric deposition of mercury, which could add to total mercury in sediments and tailings in the area (Fitzgerald and others, 1998). Notable increases in mercury concentrations in soils and sediments from atmospheric deposition, however, are likely to be restricted to within a few centimeters of the surface (see, e.g., Rood and others, 1995). Also we have not yet attempted to evaluate mercury vapor emission and redeposition, which could reduce or redistribute mercury. The observation that finer grain-size materials generally show the highest mercury concentrations, which is anticipated based on the gold recovery processes used, suggests that gold mining is the main source of mercury in the area.

\section{Effect of Sample Treatment on Analytical Results, and Implications}

About 60 percent of the sediment and tailings samples, both wet and dry, were analyzed by both Chemex and Frontier laboratories using different methods of preparation and analysis (see section on analytical methods for sediments and rocks, and Table 2).

Results are compared in Figure 12. Identical results fall on the 1:1 line in the figure. The lines on either side of the 1:1 line show a two-standard deviation analytical error envelope. The analytical error is not rigorously determined from replicate analysis, but rather is estimated from laboratory experience. The comparison plot demonstrates that samples with low mercury concentrations (less than $30 \mathrm{ng} / \mathrm{g}$ ) show similar results by both 
methods. At higher mercury concentrations, samples whose median grain size is sand size or smaller also yield similar results by both methods. Results that fall outside the envelope, considered likely to be significantly different, are all for samples with large median grain size, and in all cases the Frontier analyses show the higher mercury values. Because the Frontier analysis method does not include material from the silicate clasts, which are likely low in mercury, this indicates that much of the mercury present is associated with sand or smaller grain sizes and localized in aqua regia-leachable mineral grains or coatings on silicate grains. The mercury in leachable grains and coatings is also incorporated in the Chemex analyses, but the pulverization and digestion includes lowmercury material from clasts. Although mercury losses from the Chemex drying step cannot be ruled out, the similarity between Chemex and Frontier results for other samples, especially those having relatively high mercury concentrations and relatively small grain size, suggest that such losses are not significant.

\section{Results For Waters}

Figure 13 shows results for waters, which were sampled at the same sites as wet sediments (Figures 10 and 11; data in Tables 5 and 6). The stacked bars show the total mercury concentrations, as well as proportions of dissolved versus suspended mercury. "Dissolved" mercury is here operationally defined as the concentration of mercury measured in an aliquot passing a $0.45 \mu \mathrm{m}$ filter. The filtration was done in the laboratory under ultra-clean mercury-free conditions (see section on analytical methods for waters).

Except for water impounded at the outlet of the hydraulic mine drainage tunnel, total mercury values are generally low, and similar to many values for waters obtained elsewhere in the Sacramento River Basin (Domagalski, 1998; Domagalski and others, $2000 \mathrm{a}, \mathrm{b})$. In all cases the majority of the mercury present (about $60-90$ percent) is associated with suspended particles, which is also typical of waters elsewhere in the Sacramento River basin. Proposed aquatic life criteria for total mercury in water span a wide range. As is the case with the criterion for sediment, this is the level above which there is evidence of potential for observable effects in biota, not necessarily including bioaccumulation and biomagnification. The lowest proposed criterion for chronic effects in fresh-water aquatic life (12 ng/L total recoverable mercury) is shown on Figure 13 for reference. It was first recommended by EPA in 1986, and is the level recommended by BLM's National Applied Resource Sciences Center (Barkow, 1999). In April 1999 EPA issued a guideline of $770 \mathrm{ng} / \mathrm{L}$ (dissolved mercury) for chronic effects in fresh-water aquatic life. The $50 \mathrm{ng} / \mathrm{L}$ level shown on Figure 13 is the California Water Quality Standard. This number, proposed in 1997, refers to total recoverable mercury and is a human health standard. Only the drainage tunnel sample exceeds the $12 \mathrm{ng} / \mathrm{L}$ level, but low values are generally anticipated during the low-flow late-summer conditions under which we obtained the samples. 
With the exception of the Igo Gauge site, where mercury is low in all media, total mercury values in waters show no obvious correlation with mercury levels in bulk or fine sediments at the same sites.

Figure 14 shows amounts of methylmercury versus total mercury for unfiltered waters. Lines of equal proportions of methylmercury are shown for reference (note that the scales for both axes and the intervals between the percentage lines are logarithmic). Methylmercury values for most of the stream and pond waters fall within the range seen elsewhere in the Sacramento River Basin (Domagalski, 1998, 2000b). In these waters between 1 and 10 percent of total mercury is methylmercury, which is within the range of values commonly seen in relatively uncontaminated surface waters with normal methylation potential (see e.g., Kelly and others, 1995). Proportions of methylmercury are high in Red Pond and Pond 3, producing absolute values higher than those reported by Domagalski (1998, 2000b). At the time of sampling these ponds were shallow, warm, and contained decaying organic matter. The high proportion of methylmercury in Pond 3 is particularly significant, as it shows that conditions in shallow ponds on the flood plain may favor methylation of mercury. Further work is needed to explain the extraordinarily low methylmercury level seen in water in the hydraulic drainage tunnel.

Sulfate values are in the normal range seen in West Coast rivers (Hem and others, 1990); however, values in East Pond and the hydraulic drainage tunnel are comparable to the highest values seen in river waters (Figure 15). Prospect tunnels in the gravels of the Tehama Formation exposed above Red Pond in the Spring Creek valley contain finegrained pyrite that is now being oxidized, because the tunnels provide drainage and have thus lowered the water table. At the time of sampling, a small area of pyrite-bearing conglomerate was also exposed at the north edge of the Clear Creek flood plain near Pond 3. This exposure was too small to determine its relations to other units, but it probably represents Tehama Formation material covered by thin Recent alluvium. These exposures suggest that the Tehama Formation contains pyrite-bearing reduced zones. Where exposed to oxidation, these zones could be sources of sulfate in waters.

Figure 15 shows that in the Clear Creek area sample suite, waters with relatively high sulfate concentrations also have relatively high total mercury values. Methylmercury, however, shows no consistent relationship to sulfate, because methylmercury levels in Red Pond and Pond 3 are relatively high, whereas the methylmercury level in the hydraulic drainage tunnel water is relatively low (Figure 14).

Iron concentrations vary greatly in the waters sampled (Figure 16), but are high only in the Red Pond, as anticipated from the observation that iron oxyhydroxide precipitates on the bottom and on pond vegetation during the summer months (Figure 7). The high iron in Red Pond can be explained in light of other chemical characteristics, as discussed below. Pond 3 showed surprisingly high iron, although no iron mineral precipitates were observed. The source of iron in Pond 3 is not obvious, but oxidizing sulfides in nearby bedrock are a possible source for iron, as well as sulfate. Note that data for filtered 
samples are used in Figure 16, because we do not have unfiltered iron data for all samples. In all cases where we have iron analyses for both unfiltered and filtered subsamples, the unfiltered values are several times the filtered values. This indicates that the majority of iron in the waters is present in suspension, probably as iron oxyhydroxide particles or coatings on other particles, a condition that is commonly seen in natural waters.

Chloride concentrations (Figure 17) in pond and stream waters, which fall between about 1.5 and $5 \mathrm{ppm}$, are in the normal range for surface waters near the Pacific Ocean (Hem and others, 1990). The higher concentrations in East Pond and Pond 3 (about 10-15 ppm) are within the range seen, but since both are shallow small-volume ponds, the values more likely reflect effects of evapoconcentration.

Red Pond has an extremely high chloride concentration $(13,000 \mathrm{mg} / \mathrm{L})$, approaching that of seawater (approximately 30,000 mg/L). High-chloride waters that represent connate fluids from the Great Valley sequence at depth appear in springs to the south along the west side of the Sacramento Valley, and contribute to fluids in The Geysers geothermal field (Donnelly-Nolan and others, 1993) and to ore-forming fluids and groundwaters at the McLaughlin gold deposit (Rytuba and others, 1993). A contribution from such highsalinity fluid probably also accounts for the elevated chloride concentration in the hydraulic mine drainage tunnel. Although such fluids may be enriched in mercury, total mercury does not correlate with chloride at these two sites.

High boron and lithium values are distinguishing geochemical features of the Great Valley connate fluids. As Figure 18 shows, high concentrations of these elements accompany the chloride in the Red Pond water, and confirm that connate water is a major component in the seeps that feed Red Pond. The intermediate boron and lithium values seen in the hydraulic drainage tunnel water, in approximately the same ratio to Red Pond water as chloride, confirm that it contains a small contribution of connate water. The contributions of connate waters at these sites suggests that waters of deep-seated origin may contribute mercury to the surface environment in the Clear Creek area, and that gold mining may not be the only source of mercury.

\section{Conclusions}

The following preliminary conclusions are drawn from the results of mercury determinations reported here.

1) Background mercury values are low, as determined from bedrock, clasts in gravels, and unmined auriferous gravels.

2) Bulk mercury values in sediments and tailings are elevated to as much as several times background concentrations. 
3) Mercury and methylmercury in sediments and tailings are associated with fine grainsize fractions.

4) Mercury and methylmercury values are relatively low in Clear Creek stream waters and ponds on the Clear Creek flood plain.

5. High-salinity connate waters enter the surface environment in the area through springs and seeps. Some mercury in waters in the area may be from this source.

These conclusions are considered preliminary, primarily because the number of sample sites is relatively small, and the data for waters are derived from only one sampling event. Thus for solids, spatial variations cannot be evaluated and the full range of mercury values cannot be determined. For waters, which vary both spatially and temporally, a single sampling event is not enough for reliable characterization.

Characterization of mercury concentrations and speciation in inorganic media of the Clear Creek system will continue in 2002 and 2003, in coordination with studies of mercury in biota. Detailed studies of mercury mobility are underway, focussed on finegrained size fractions, and colloids that may be released from sediments and tailings.

\section{References}

Albers, J.P., 1964, Geology of the French Gulch quadrangle, Shasta and Trinity Counties, California: U.S. Geological Survey Bulletin 1141-J, 70 p.

Averill, C.V., 1933, Gold deposits of the Redding and Weaverville quadrangles: California Division of Mines Report 29, p. 3-73.

Barkow, Lee, 1999, Site characterization for abandoned mine/mill sites, modification 1: U.S. Bureau of Land Management, National Applied Resource Sciences Center, Information Bulletin No. RS-2000-021, November 18, 1999, 3 p.

Bloom, N.S., 1989, Determination of picogram levels of methylmercury by aqueous phase ethylation, followed by cryogenic gas chromatography with cold vapour atomic fluorescence detection: Canadian Journal of Fisheries and Aquatic Sciences, v. 46, p. 1131-1140.

Bloom, N.S., 1995, Mercury as a case study of ultra-clean sample handling and storage in aquatic trace metal research: Environmetal Laboratory, v. 3-4, p. 20-25.

Bloom, N.S., Crecelius, E.A., and Fitzgerald, W.F., 1988, Determination of volatile mercury species at the picogram level by low temperature gas chromatography with 
cold vapor atomic fluorescence detection: Analytica Chimica Acta, v. 208, p. 151161.

Clark, W.B., 1970, Gold districts of California: California Division of Mines and Geology Bulletin 193, 186 p.

Crock, J.G., 1996, Mercury: Chapter 29 in Sparks, D.L., ed., Methods of Soil Analysis, Part 3, Chemical Methods: Soil Science Society of America Book Series, Number 5, p. $769-791$.

Domagalski, J., 1998, Occurrence and transport of total mercury and methyl mercury in the Sacramento River basin, California: Journal of Geochemical Exploration, v. 64, p. 277-291.

Domagalski, J.L., Dileanis, P.D., Knifong, D.L., Munday, C.M., May, J.T., Dawson, B.J., Shelton, J.L., and Alpers, C.N., 2000a, Water-quality assessment of the Sacramento River Basin, California: water-quality, sediment and tissue chemistry, and biological data, 1995-1998, U.S. Geological Survey Open-File Report 00-391, http:// water.wr.usgs.gov/sac\%5Fnawqa/waterindex.html.

Domagalski, J.L., Knifong, D.L., Dileanis, P.D., Brown, L.R., May, J.T., Connor, Valerie, and Alpers, C.N., 2000b, Water quality in the Sacramento River Basin, California, 1994-1998: U.S. Geological Survey Circular 1215, 36 p.

Donnelly-Nolan, J.M., Burns, M.G., Goff, F.E., Peters, E.K., and Thompson, J.M., 1993, The Geysers-Clear Lake area, California-thermal waters, mineralization, volcanism, and geothermal potential: Economic Geology, v. 88, p. 301-316.

Evernden, J.F., Savage, D.E., Curtis, G.H., and James, G.J., 1964, Potassium-argon dates and the Cenozoic mammalian chronology of North America: American Journal of Science, v. 262, p. 145-198.

Fishman, M.J. and Pyen, G., 1979, Determination of selected anions in water by ion chromatography: U.S. Geol. Survey Water Resources Invest. 79-101, 30 p.

Fitzgerald, W.F., Engstrom, D.R., Mason, R.P., and Nater, E.A., 1998, The case for atmospheric mercury contamination in remote areas: Environmental Science and Technology, v. 32, p. 1-7.

Gill, G.A. and Fitzgerald, W.F., 1987, Picomolar mercury measurements in seawater and other materials using stannous chloride reduction and two-stage gold amalgamation with gas phase detection: Marine Chemistry, v. 20, p. 227-243. 
Fraticelli, L.A., Albers, J.P., Irwin, W.P., and Blake, M.C., Jr., 1987, Geologic map of the Redding 1x2 degree quadrangle, Shasta, Tehama, Humboldt, and Trinity Counties, California: U.S. Geological Survey Open-File Report 87-257, scale 1:250,000, text 24 p.

Helley, E.J., and Harwood, D.S., 1985, Geologic map of the Late Cenozoic deposits of the Sacramento Valley and Northern Sierran Foothills, California: U.S. Geological Survey Miscellaneous Field Investigations Series Map MF-1790, scale 1:62,500 (Sheet 5 of 5), text 24 p.

Hem, J.D., Demayo, Adrian, and Smith, R.A., 1990, Hydrochemistry of rivers and lakes, Chapter 9 in Wolman, M.G., and Riggs, H.C., eds., Surface Water Hydrology: Geological Society of America, The Geology of North America, v. O-1, p. 189-232.

Horvat, Milena, Bloom, N.S., and Liang, Lian, 1993, Comparison of distillation with other current isolation methods for the determination of methyl mercury compounds in low level environmental samples; Part 1, Sediments: Analytica Chimica Acta, v. 281, p. 135-152.

Irwin, W.P., 1972, Terranes of the western Paleozoic and Triassic belt in the Southern Klamath Mountains, California: U.S. Geological Survey Professional Paper 800-C, p. C103-C111.

Irwin, W.P., 1981, Tectonic accretion of the Klamath Mountains, in Ernst, W.G., ed., The Geotectonic Development of California: Prentice-Hall, New Jersey, p. 29-49.

Irwin, W.P., 1985, Age and tectonics of plutonic belts in accreted terranes of the Klamath Mountains, California and Oregon, in Howell, D.G., ed., Tectonostratigraphic Terranes of the Circum-Pacific Region: Circum-Pacific Council for Energy and Mineral Resources, Earth Science Series, v. 1, p. 187-199.

Kelly, C.A., Rudd, J.W.M., St. Louis, V.L., and Heyes, Andrew, 1995, Is total mercury concentration a good predictor of methyl mercury concentration in aquatic systems?: Water, Air, and Soil Pollution, v. 80, p. 715-724.

Kinkel, A.R., Jr., Hall, W.E., and Albers, J.P., 1956, Geology and base-metal deposits of the West Shasta copper-zinc district, Shasta County, California: U.S. Geological Survey Professional Paper 285, 156 p.

National Research Council of Canada Institute for National Measurement Standards, 1999, DORM-2, DOLT-2, Dogfish muscle and liver certified reference materials for trace metals: INMS Certified Reference Materials Data Sheet, http://www.ems.nrc.ca/ ems 1.htm , 4 p. 
O'Leary, R.M., Hageman, P.L., and Crock, J.G., 1996, Determination of mercury in water, geologic, and plant materials by continuous flow-cold vapor-atomic absorption spectrophotometry, in Arbogast B.F., ed., Quality Assurance Manual for the Branch of Geochemistry, U.S. Geological Survey: U.S. Geological Survey Open File Report 96525, p. $42-55$.

Orion Research, Inc., 1978, Analytical methods guide ( $9^{\text {th }}$ ed.): Cambridge, MA, 48 p.

Rood, B.E., Gottgens, J.F., Delfino, J.J., Earle, C.D., and Crisman, T.L., 1995, Mercury accumulation trends in Florida Everglades and Savannas Marsh flooded soils: Water, Air and Soil Pollution, v. 80, p. 981-990.

Rytuba, J.J., Enderlin, D.A., McLaughlin, R.J., and Donnelly-Nolan, J.M., 1993, McLaughlin gold and Knoxville mercury deposits-road log, in Rytuba, J.J., ed., Active Geothermal Systems and Gold-mercury deposits in the Sonoma-Clear Lake Volcanic Fields, California: Society of Economic Geologists Guidebook Series 16, p. 350-361.

Strand, R.G. (compiler), 1962, Geologic map of California, Redding sheet: scale $1: 250,000$.

U.S. Environmental Protection Agency, 1997, The incidence and severity of sediment contamination in surface waters of the United States, Volume 1-National Sediment Quality Survey: Office of Science and Technology, EPA-823-R-97-006, 6 separatelynumbered chapters and 9 appendices.

Yahnke, J.W., 2001, Lower Clear Creek rehabilitation project-potential mercury contamination of sediments for use as spawning gravels: Bureau of Land Management, Land Suitability and Water Quality Group, Technical Service Center Report, Denver, Colorado, April 19, 2001, 5 p. 


\begin{tabular}{|c|c|c|c|c|c|c|c|c|c|c|c|c|c|c|}
\hline \multirow{2}{*}{$\begin{array}{l}\text { Field } \\
\text { no. }\end{array}$} & \multirow{2}{*}{$\begin{array}{c}\text { Map } \\
\text { no. }\end{array}$} & \multirow[t]{2}{*}{ Latitude } & \multirow[t]{2}{*}{ Longitude } & \multicolumn{4}{|c|}{ SEDIMENT SAMPLES } & \multicolumn{6}{|c|}{ WATER SAMPLES } & \multirow[t]{2}{*}{ Description } \\
\hline & & & & $\begin{array}{c}\text { Bulk } \\
\text { sediment }\end{array}$ & $\begin{array}{l}\text { Sediment } \\
>2 \mathrm{~mm}\end{array}$ & $\begin{array}{l}\text { Sediment } \\
<2 \mathrm{~mm}\end{array}$ & $\begin{array}{l}\text { Sediment } \\
<63 \text { um }\end{array}$ & $\begin{array}{c}\text { Unfiltered } \\
\text { unacidified }\end{array}$ & $\begin{array}{c}\text { Filtered } \\
\text { unacidified }\end{array}$ & $\begin{array}{l}\text { Filtered } \\
\text { acidified }\end{array}$ & $\begin{array}{l}\text { Unfiltered } \\
\text { acidified }\end{array}$ & Alkalinity & $\begin{array}{l}\text { Total } \\
\text { carbon }\end{array}$ & \\
\hline $21 \mathrm{CC} 01$ & 1 & $40^{\circ} 29.911^{\prime}$ & $122^{\circ} 24.942^{\prime}$ & 21CC01WAS & & & $\underset{\mathrm{F}}{21 \mathrm{CC} 01 \mathrm{WBS}}$ & $21 \mathrm{CC} 01 \mathrm{~W}$ & 21CC01WA & $21 \mathrm{CC} 01 \mathrm{WB}$ & & 21CC01Wd & $\underset{C}{21 \mathrm{CC} 01 \mathrm{WT}}$ & $\begin{array}{l}\text { South Pond, north side, } \\
\text { clear }\end{array}$ \\
\hline $21 \mathrm{CC} 02$ & 2 & $40^{\circ} 30.259^{\prime}$ & $122^{\circ} 24.419^{\prime}$ & 21CC02WBS & & & $\underset{\mathrm{F}}{21 \mathrm{CC} 02 \mathrm{WAS}}$ & $21 \mathrm{CC} 02 \mathrm{~W}$ & 21CC02WA & 21CC02WB & & $21 \mathrm{CC} 02 \mathrm{Wd}$ & $\underset{\mathrm{C}}{21 \mathrm{CC} 02 \mathrm{WT}}$ & East Pond \\
\hline $21 \mathrm{CC} 03$ & 3 & $40^{\circ} 29.871^{\prime}$ & $122^{\circ} 24.925^{\prime}$ & $\begin{array}{r}21 C C 03 S A \\
21 \text { CC03WSAB }\end{array}$ & & & $\begin{array}{c}\text { 21CCO3WSF } \\
\text { B }\end{array}$ & $21 \mathrm{CC} 03 \mathrm{~W}$ & 21CC03WA & 21CC03WB & $21 \mathrm{CC} 03 \mathrm{WC}$ & $21 \mathrm{CC} 03 \mathrm{Wd}$ & 21CC03TC & $\begin{array}{l}\text { South Pond, south side, } \\
\text { turbid }\end{array}$ \\
\hline $21 \mathrm{CC} 04$ & 4 & $40^{\circ} 29.886^{\prime}$ & $122^{\circ} 24.997^{\prime}$ & $21 \mathrm{CC} 04 \mathrm{SA}$ & & & & & & & & & & $\begin{array}{l}\text { Fill material, west side of } \\
\text { South Pond }\end{array}$ \\
\hline $21 \mathrm{CC} 05$ & 5 & $40^{\circ} 29.886^{\prime}$ & $122^{\circ} 24.997^{\prime}$ & 21CC05S & & & & & & & & & & $\begin{array}{l}\text { Composite of metamorpic- } \\
\text { rock pebbles from fill, west } \\
\text { side of South Pond }\end{array}$ \\
\hline $21 \mathrm{CC} 06$ & 6 & $40^{\circ} 29.886^{\prime}$ & $122^{\circ} 24.997^{\prime}$ & $21 \mathrm{CC} 06 \mathrm{~S}$ & & & & & & & & & & $\begin{array}{l}\text { Composite of igneous-rock } \\
\text { pebbles from fill, west side } \\
\text { of South Pond }\end{array}$ \\
\hline $21 \mathrm{CC} 07$ & 7 & $40^{\circ} 30.026^{\prime}$ & $122^{\circ} 24.926^{\prime}$ & $\begin{array}{c}21 \mathrm{CC} 07 \mathrm{~S} \\
21 \mathrm{CC} 07 \mathrm{ASB}\end{array}$ & & & 21CC07B & $21 \mathrm{CC} 07 \mathrm{~W}$ & $21 \mathrm{CC} 07 \mathrm{~A}$ & 21CC07Wb & $21 \mathrm{CC} 07 \mathrm{Wc}$ & $21 \mathrm{CC} 07 d$ & & Pond 3 \\
\hline $21 \mathrm{CC} 08$ & 8 & $40^{\circ} 29.795^{\prime}$ & $122^{\circ} 27.476^{\prime}$ & & $21 \mathrm{CC} 08 \mathrm{SC}$ & $\begin{array}{l}21 \mathrm{CC} 08 \mathrm{SF} 1 \\
21 \mathrm{CC} 08 \mathrm{SF} 2 \\
\end{array}$ & & & & & & & & $\begin{array}{l}\text { Coarse tailings (pebbles, } \\
\text { cobbles) at drainage cut }\end{array}$ \\
\hline $21 C C 09$ & 9 & $40^{\circ} 29.795^{\prime}$ & $122^{\circ} 27.476^{\prime}$ & $21 \mathrm{CC} 09 \mathrm{~S}$ & & & & & & & & & & $\begin{array}{l}\text { Nomlaki Tuff at drainage } \\
\text { cut }\end{array}$ \\
\hline $21 \mathrm{CC} 10$ & 10 & $40^{\circ} 29.700^{\prime}$ & $122^{\circ} 27.300^{\prime}$ & $\begin{array}{l}21 \mathrm{CC} 10 \mathrm{SB} 1 \\
21 \mathrm{CC} 10 \mathrm{SB} 2\end{array}$ & & & & & $21 \mathrm{CC} 10 \mathrm{~A}$ & $21 \mathrm{CC} 10 \mathrm{c}$ & $21 \mathrm{CC} 10 \mathrm{~b}$ & $21 \mathrm{CC} 10 \mathrm{~d}$ & & $\begin{array}{l}\text { Water ponded on tailings } \\
\text { at outlet of drainage tunnel }\end{array}$ \\
\hline $21 \mathrm{CC} 11$ & 11 & $40^{\circ} 29.719^{\prime}$ & $122^{\circ} 27.393^{\prime}$ & $\begin{array}{l}21 \mathrm{CC} 11 \mathrm{SB} 1 \\
21 \mathrm{CC} 11 \mathrm{SB} 2\end{array}$ & 21CC11SC & 21CC11SF & 21CC11SVF & 21CC11W & $21 \mathrm{CC} 11 \mathrm{~A}$ & $21 \mathrm{CC} 11 \mathrm{~b}$ & & 21CC11d & & $\begin{array}{l}\text { Bed of Clear Creek and } \\
\text { gravel bar upstream from } \\
\text { (west of) project area }\end{array}$ \\
\hline $21 \mathrm{CC} 12$ & 12 & $40^{\circ} 30.038^{\prime}$ & $122^{\circ} 29.257^{\prime}$ & $21 \mathrm{CC} 12 \mathrm{~B}$ & & & & $21 \mathrm{CC} 12 \mathrm{~W}$ & $21 \mathrm{CC} 12 \mathrm{~A}$ & $\begin{array}{c}21 \mathrm{CC} 12 \mathrm{~B} \\
1,2 \\
\end{array}$ & & $21 \mathrm{CC} 12 \mathrm{~d}$ & & Red Pond \\
\hline $21 \mathrm{CC} 13$ & 13 & $40^{\circ} 30.076^{\prime}$ & $122^{\circ} 29.236^{\prime}$ & $21 \mathrm{CC} 13 \mathrm{~B}$ & $21 \mathrm{CC} 13 \mathrm{SC}$ & $\begin{array}{l}\text { 21CC13SF1 } \\
\text { 21CC13SF2 }\end{array}$ & & & & & & & & $\begin{array}{l}\text { Drift-mine tunnel in gravels } \\
\text { beneath Nomlaki Tuff, } \\
\text { near Red Pond }\end{array}$ \\
\hline $21 \mathrm{CC} 13$ & 13 & $40^{\circ} 30.076^{\prime}$ & $122^{\circ} 29.236^{\prime}$ & 21CC13ST & & & & & & & & & & $\begin{array}{l}\text { Nomlakai Tuff at drift-mine } \\
\text { tunnel, near Red Pond }\end{array}$ \\
\hline $21 \mathrm{CC} 14$ & 14 & $40^{\circ} 29.911^{\prime}$ & $122^{\circ} 29.169^{\prime}$ & $21 \mathrm{CC} 14 \mathrm{SB}$ & $21 \mathrm{CC} 14 \mathrm{SC}$ & $\begin{array}{l}\text { 21CC14SF1 } \\
\text { 21CC14SF2 }\end{array}$ & & & & & & & & $\begin{array}{l}\text { Dredge stacker tailings, } \\
\text { Spring Creek }\end{array}$ \\
\hline $21 \mathrm{CC} 15$ & 15 & $40^{\circ} 29.734^{\prime}$ & $122^{\circ} 29.150^{\prime}$ & $\begin{array}{l}21 \mathrm{CC} 15 \mathrm{CL} 1 \\
21 \mathrm{CC} 15 \mathrm{CL} 2\end{array}$ & & & & & & & & & & $\begin{array}{l}\text { Sluice tailings (clay-silt) } \\
\text { exposed in backhoe } \\
\text { trench, Shooting Gallery }\end{array}$ \\
\hline $21 \mathrm{CC} 15$ & 15 & $40^{\circ} 29.734^{\prime}$ & $122^{\circ} 29.150^{\prime}$ & $\begin{array}{l}\text { 21CC15SC1 } \\
21 \mathrm{CC} 15 \mathrm{SC} 2\end{array}$ & & & & & & & & & & $\begin{array}{l}\text { Sluice tailings (coarse } \\
\text { sand) exposed in backhoe } \\
\text { trench, Shooting Gallery }\end{array}$ \\
\hline $21 \mathrm{CC} 15$ & 15 & $40^{\circ} 29.734^{\prime}$ & $122^{\circ} 29.150^{\prime}$ & $\begin{array}{l}\text { 21CC15SF1 } \\
21 \text { CC15SF2 }\end{array}$ & & & & & & & & & & $\begin{array}{l}\text { Sluice tailings (fine sand) } \\
\text { exposed in backhoe } \\
\text { trench, Shooting Gallery }\end{array}$ \\
\hline $21 \mathrm{CC} 16$ & 16 & $40^{\circ} 29.734^{\prime}$ & $122^{\circ} 29.150^{\prime}$ & $\begin{array}{l}21 \mathrm{CC} 16 \mathrm{~B} \\
21 \mathrm{CC} 16 \mathrm{SB}\end{array}$ & 21CC16SC & 21CC16SF & & & & & & & & $\begin{array}{l}\text { Stacker tailings (cobbles, } \\
\text { pebbles, sand) in backhoe } \\
\text { trench, Shooting Gallery }\end{array}$ \\
\hline $21 \mathrm{CC} 17$ & 17 & $40^{\circ} 29.753^{\prime}$ & $122^{\circ} 29.150^{\prime}$ & 21CC17SB & $21 \mathrm{CC} 17 \mathrm{SC}$ & $\begin{array}{l}21 \mathrm{CC} 17 \mathrm{SF} 1 \\
21 \mathrm{CC} 17 \mathrm{SF} 2 \\
\end{array}$ & & & & & & & & $\begin{array}{l}\text { Dredge stacker tailings, } \\
\text { Spring Creek }\end{array}$ \\
\hline $21 \mathrm{CC} 18$ & 18 & $40^{\circ} 30.862^{\prime}$ & $122^{\circ} 31.487^{\prime}$ & $\begin{array}{l}21 \mathrm{CC} 18 \mathrm{SB} 1 \\
21 \mathrm{CC} 18 \mathrm{SB} 2\end{array}$ & & & & 21CC18W & 21CC18WA & \begin{tabular}{|c|}
$21 \mathrm{CC} 18 \mathrm{WB}$ \\
1,2
\end{tabular} & $\begin{array}{c}21 \mathrm{CC} 18 \mathrm{WC} \\
1,2\end{array}$ & $21 \mathrm{CC} 18 w d$ & & $\begin{array}{l}\text { Bed of Clear Creek at } \\
\text { USGS Gauging Station }\end{array}$ \\
\hline $21 \mathrm{CC} 19$ & 19 & $40^{\circ} 30.862^{\prime}$ & $122^{\circ} 31.487^{\prime}$ & $\begin{array}{l}21 \mathrm{CC} 19 \mathrm{SB} 1 \\
21 \mathrm{CC} 19 \mathrm{SB} 2\end{array}$ & & & & & & & & & & $\begin{array}{l}\text { Beach sand at USGS } \\
\text { Gauging Station, Clear } \\
\text { Creek }\end{array}$ \\
\hline
\end{tabular}

Color code:

Red: analyzed by Frontier Geosciences, Inc.

Black: analyzed by U.S. Geological Survey, Mineral Resource Surveys, Denver 
Table 2. Comparison of preparation and analytical procedures used for solid samples by ALS Chemex and Frontier Geosciences laboratories

\begin{tabular}{|c|c|c|}
\hline & ALS Chemex & Frontier Geosciences \\
\hline \multicolumn{3}{|l|}{ Step (in sequence) } \\
\hline (1) Dry & $60^{\circ} \mathrm{C}$ & - \\
\hline (2) Remove split & $250 \mathrm{~g}$ & $0.5 \mathrm{~g}$ \\
\hline (3) Pulverize & To $>85 \%<75 \mu$ & - \\
\hline (4) Digest/leach & $\mathrm{HF}-\mathrm{HNO}_{3}-\mathrm{HClO}_{4}-\mathrm{HCl}$ & Aqua regia $\left(\mathrm{HCl}-\mathrm{HNO}_{3}\right)$ \\
\hline (5) Analysis* & CVAA & CVAFS \\
\hline
\end{tabular}

* Mercury detection method only. The same chemical procedure for extraction of mercury from solid samples is used by both laboratories. 
Table 3. Mercury and methylmercury concentrations in dredge tailings and sediment samples

\begin{tabular}{|c|c|c|c|c|c|c|}
\hline Field site & $\begin{array}{c}\text { Map } \\
\text { no. }\end{array}$ & $\begin{array}{c}\text { Subsample } \\
\text { number }\end{array}$ & $\begin{array}{c}\text { Sample } \\
\text { material }\end{array}$ & $\begin{array}{l}\text { Total Hg, ppb } \\
\text { Chemex }\end{array}$ & $\begin{array}{l}\text { Total } \mathrm{Hg}, \mathrm{ppb} \\
\text { Frontier }\end{array}$ & $\begin{array}{l}\text { Methyl } \mathrm{Hg}, \mathrm{ppb} \\
\text { Frontier }\end{array}$ \\
\hline \multirow[t]{2}{*}{ 21CC01 } & 1 & 21CC01WAS & Bulk & & 134 & 0.588 \\
\hline & & 21CC01WBSF & $<63 \mu \mathrm{m}$ & & 295 & 1.18 \\
\hline \multirow{2}{*}{ 21CC02 } & 2 & 21CC02WBS & Bulk & & 24.9 & 0.639 \\
\hline & & 21CC02WASF & $<63 \mu \mathrm{m}$ & & 190 & 2.07 \\
\hline \multirow[t]{3}{*}{$21 \mathrm{CCO} 3$} & 3 & $21 \mathrm{CC} 03 S A$ & Bulk & 90 & & \\
\hline & & 21CC03WSAB & Bulk & & 109 & 0.225 \\
\hline & & 21CC03WSFB & $<63 \mu \mathrm{m}$ & & 269 & 1.02 \\
\hline $21 \mathrm{CCO} 04$ & 4 & 21CC04SA & Bulk & 30 & & \\
\hline 21CC05 & 5 & $21 \mathrm{CC} 05 \mathrm{~S}$ & Bedrock & 30 & & \\
\hline 21CC06 & 6 & 21CC06S & Bedrock & $<10$ & & \\
\hline \multirow[t]{3}{*}{ 21CC07 } & 7 & 21CC07S & Bulk & 30 & & \\
\hline & & 21CC07ASB & Bulk & & 22.9 & 0.574 \\
\hline & & 21CC07B & $<63 \mu \mathrm{m}$ & & 275 & 3.00 \\
\hline \multirow[t]{2}{*}{$21 C C 08$} & 8 & $21 \mathrm{CCO} 0 \mathrm{SC}$ & $>2 \mathrm{~mm}$ & 20 & & \\
\hline & & 21CC08SF1,2 & $<2 \mathrm{~mm}$ & 30 & 60.1 & 0.387 \\
\hline 21CC09 & 9 & 21CC09S & Bedrock & $<10$ & & \\
\hline $21 \mathrm{CC} 10$ & 10 & 21CC10SB1,2 & Bulk & 70 & 114 & 0.299 \\
\hline \multirow[t]{4}{*}{ 21CC11 } & 11 & 21CC11SB1,2 & Bulk & 40 & 118 & 0.699 \\
\hline & & 21CC11SC & $>2 \mathrm{~mm}$ & 30 & & \\
\hline & & 21CC11SF & $<2 \mathrm{~mm}$ & 60 & & \\
\hline & & 21CC11SVF & $<63 \mu \mathrm{m}$ & & 204 & 0.775 \\
\hline 21CC12 & 12 & $21 \mathrm{CC} 12 \mathrm{~B}$ & Bulk & & 160 & 31.1 \\
\hline \multirow[t]{4}{*}{$21 \mathrm{CC} 13$} & 13 & 21CC13B & Bulk & $<10$ & & \\
\hline & & 21CC13SC & $>2 \mathrm{~mm}$ & $<10$ & & \\
\hline & & 21CC13SF1,2 & $<2 \mathrm{~mm}$ & $<10$ & 2.89 & $<0.015$ \\
\hline & & 21CC13ST & Bedrock & $<10$ & & \\
\hline \multirow[t]{3}{*}{ 21CC14 } & 14 & 21CC14SB & Bulk & 50 & & \\
\hline & & $21 \mathrm{CC} 14 \mathrm{SC}$ & $>2 \mathrm{~mm}$ & 30 & & \\
\hline & & 21CC14SF1,2 & $<2 \mathrm{~mm}$ & 40 & 51.0 & 0.064 \\
\hline \multirow[t]{3}{*}{ 21CC15 } & 15 & 21CC15CL1,2 & Bulk & 160 & 134 & 0.046 \\
\hline & & 21CC15SC1,2 & Bulk & 90 & 99.5 & $<0.015$ \\
\hline & & 21CC15SF1,2 & Bulk & 90 & 104 & $<0.015$ \\
\hline \multirow[t]{4}{*}{$21 \mathrm{CC} 16$} & 16 & 21CC16B & Bulk & 70 & & \\
\hline & & 21CC16SB & Bulk & & 202 & 0.026 \\
\hline & & 21CC16SC & $>2 \mathrm{~mm}$ & 40 & & \\
\hline & & $21 \mathrm{CC} 16 \mathrm{SF}$ & $<2 \mathrm{~mm}$ & 140 & & \\
\hline \multirow[t]{3}{*}{$21 \mathrm{CC} 17$} & 17 & 21CC17SB & Bulk & 60 & & \\
\hline & & 21CC17SC & $>2 \mathrm{~mm}$ & 20 & & \\
\hline & & 21CC17SF1,2 & $<2 \mathrm{~mm}$ & 40 & 29.7 & 0.101 \\
\hline 21CC18 & 18 & 21CC18SB1,2 & Bulk & 20 & 22.5 & 0.188 \\
\hline 21CC19 & 19 & 21CC19SB1,2 & Bulk & 20 & 13.1 & 0.020 \\
\hline
\end{tabular}


Table 4. Concentrations of major and minor elements in dredge tailings and sediment samples, determined by ICP-MS and ICP-AES

\begin{tabular}{|c|c|c|c|c|c|c|c|c|c|c|c|c|c|c|}
\hline Field site & Map no. & Subsample no. & Sample mtl & $\mathrm{Ag}$ & $\begin{array}{l}\mathrm{Al} \\
\%\end{array}$ & As & $\mathrm{Ba}$ & $\mathrm{Be}$ & $\mathrm{Bi}$ & $\mathrm{Ca}$ & $\mathrm{Cd}$ & $\mathrm{Ce}$ & Co & $\mathrm{Cr}$ \\
\hline & & & & ppm & & & ppm & & ppm & $\%$ & ppm & & ppm & ppm \\
\hline $21 \mathrm{CCO3}$ & 3 & $21 C C 03 S A$ & Bulk & 0.82 & 5.57 & 9 & 485.5 & 0.8 & 0.07 & 1.55 & 0.18 & 26.6 & 9.4 & 123 \\
\hline 21CC04 & 4 & $21 \mathrm{CCO} 4 \mathrm{SA}$ & Bulk & 0.6 & 5.57 & 8.8 & 460.5 & 0.6 & 0.07 & 1.7 & 0.16 & 24.5 & 9 & 105 \\
\hline 21CC05 & 5 & $21 \mathrm{CCO} 5 \mathrm{~S}$ & Bedrock & 0.46 & 3.17 & 6.2 & 542.7 & 0.55 & 0.05 & 0.17 & 0.08 & 15.1 & 2.6 & 112 \\
\hline 21CC06 & 6 & $21 \mathrm{CCO} 0 \mathrm{~S}$ & Bedrock & 0.4 & 6.52 & 1 & 650.1 & 0.9 & 0.05 & 0.72 & $<0.02$ & 16.95 & 2.2 & 57 \\
\hline 21CC07 & 7 & $21 \mathrm{CCO} 0 \mathrm{~S}$ & Bulk & 0.3 & 5.42 & 4.4 & 407 & 0.65 & 0.05 & 1.35 & 0.12 & 14.75 & 6.4 & 126 \\
\hline \multirow[t]{2}{*}{$21 C C 08$} & 8 & $21 \mathrm{CC} 08 \mathrm{SC}$ & $>2 \mathrm{~mm}$ & 0.28 & 5.27 & 4 & 471.5 & 0.75 & 0.07 & 1.35 & 0.1 & 13.85 & 5.6 & 133 \\
\hline & & 21CC08SF1 & $<2 \mathrm{~mm}$ & 0.24 & 5.59 & 3.2 & 479 & 0.75 & 0.1 & 1.2 & 0.14 & 17.6 & 6 & 156 \\
\hline 21CC09 & 9 & 21CCo9s & Bedrock & 0.3 & 7.3 & 1.6 & 867.2 & 1.35 & 0.05 & 1.3 & 0.12 & 26.8 & 4 & 51 \\
\hline $21 \mathrm{CC} 10$ & 10 & $21 \mathrm{CC} 10 \mathrm{SB} 1$ & Bulk & 0.22 & 6.29 & 7.4 & 444 & 0.85 & 0.06 & 2 & 0.12 & 16.65 & 12.3 & 168 \\
\hline \multirow[t]{3}{*}{ 21CC11 } & 11 & $21 C C 11 S B 1$ & Bulk & 0.22 & 5.86 & 7.8 & 406 & 0.7 & 0.07 & 2.5 & 0.22 & 17.4 & 7.7 & 160 \\
\hline & & $21 \mathrm{CC} 11 \mathrm{SC}$ & $>2 \mathrm{~mm}$ & 0.24 & 5.83 & 7.6 & 403.5 & 0.55 & 0.07 & 2.9 & 0.18 & 11.75 & 10.5 & 162 \\
\hline & & $21 \mathrm{CCl} 1 \mathrm{SF}$ & $<2 \mathrm{~mm}$ & 0.22 & 5.57 & 9.8 & 459.5 & 0.75 & 0.1 & 1.65 & 0.14 & 31.4 & 5.1 & 163 \\
\hline \multirow[t]{4}{*}{$21 \mathrm{CC} 13$} & 13 & $21 \mathrm{CC} 13 \mathrm{~B}$ & Bulk & 0.2 & 6.62 & 6.6 & 210 & 0.4 & 0.22 & 1.45 & 0.04 & 8.5 & 11.1 & 171 \\
\hline & & $21 \mathrm{CC} 13 \mathrm{SC}$ & $>2 \mathrm{~mm}$ & 0.2 & 6.99 & 6.2 & 174 & 0.55 & 0.16 & 1.65 & 0.1 & 8.2 & 14.1 & 165 \\
\hline & & 21CC13SF1 & $<2 \mathrm{~mm}$ & 0.2 & 6.42 & 7.8 & 541.1 & 0.75 & 0.22 & 1.85 & 0.14 & 13.55 & 15.8 & 202 \\
\hline & & 21CC13ST & Bedrock & 0.3 & 6.71 & 2.4 & 777.2 & 1.5 & 0.32 & 1.05 & 0.18 & 29.8 & 2.7 & 59 \\
\hline \multirow[t]{3}{*}{ 21CC14 } & 14 & 21CC14SB & Bulk & 0.22 & 5.29 & 5.4 & 544.3 & 0.75 & 0.09 & 1.5 & 0.16 & 18.8 & 9.5 & 143 \\
\hline & & $21 \mathrm{CC} 14 \mathrm{SC}$ & $>2 \mathrm{~mm}$ & 0.26 & 5.1 & 5.6 & 560.3 & 0.8 & 0.15 & 1.45 & 0.14 & 18.4 & 9.1 & 146 \\
\hline & & 21CC14SF1 & $<2 \mathrm{~mm}$ & 0.22 & 6.22 & 7 & 425 & 0.75 & 0.14 & 1.5 & 0.14 & 22.2 & 13.8 & 237 \\
\hline \multirow[t]{3}{*}{ 21CC15 } & 15 & 21CC15CL1 & Bulk & 0.26 & 7.34 & 7.2 & 412 & 0.85 & 0.14 & 1.45 & 0.08 & 25 & 11.5 & 109 \\
\hline & & $21 \mathrm{CC} 15 \mathrm{SCl}$ & Bulk & 0.5 & 5.3 & 5.2 & 413.5 & 0.7 & 0.07 & 1.25 & 0.06 & 23 & 6.5 & 146 \\
\hline & & 21CC15SF1 & Bulk & 0.44 & 6.03 & 5.2 & 441.5 & 0.65 & 0.07 & 1.3 & 0.06 & 28.3 & 9.6 & 162 \\
\hline \multirow[t]{3}{*}{ 21CC16 } & 16 & $21 \mathrm{CC} 16 \mathrm{~B}$ & Bulk & 0.3 & 5.88 & 5.8 & 411 & 0.7 & 0.09 & 1.4 & 0.08 & 23.3 & 10.8 & 114 \\
\hline & & 21CC16SC & $>2 \mathrm{~mm}$ & 0.36 & 5.9 & 4.4 & 327.5 & 0.55 & 0.08 & 1.6 & 0.08 & 18.35 & 9.8 & 131 \\
\hline & & $21 \mathrm{CCl} 16 \mathrm{SF}$ & $<2 \mathrm{~mm}$ & 0.32 & 6.78 & 6.6 & 427.5 & 0.8 & 0.12 & 1.35 & 0.12 & 25 & 13.3 & 177 \\
\hline \multirow[t]{3}{*}{$21 \mathrm{CC} 17$} & 17 & $21 \mathrm{CC} 17 \mathrm{SB}$ & Bulk & 0.26 & 6 & 4.4 & 299 & 0.65 & 0.1 & 2.7 & 0.1 & 12.05 & 11.5 & 156 \\
\hline & & $21 \mathrm{CC} 17 \mathrm{SC}$ & $>2 \mathrm{~mm}$ & 0.28 & 5.91 & 4.8 & 338.5 & 0.7 & 0.09 & 2.1 & 0.1 & 13.15 & 9.6 & 133 \\
\hline & & 21CC17SF1 & $<2 \mathrm{~mm}$ & 0.28 & 6.47 & 7.4 & 385.5 & 0.75 & 0.13 & 1.6 & 0.14 & 16.2 & 14.3 & 143 \\
\hline 21CC18 & 18 & 21CC18SB1 & Bulk & 0.24 & 6.13 & 4.2 & 344 & 0.85 & 0.07 & 2.3 & 0.14 & 170.5 & 7.9 & 179 \\
\hline $21 \mathrm{CC} 19$ & 19 & 21CC19SB1 & Bulk & 0.26 & 6.08 & 1.6 & 631.1 & 0.95 & 0.07 & 1.6 & 0.1 & 19.55 & 8.6 & 152 \\
\hline
\end{tabular}


Table 4. Concentrations of major and minor elements in dredge tailings and sediment samples, determined by ICP-MS and ICP-AES

\begin{tabular}{|c|c|c|c|c|c|c|c|c|c|c|c|c|c|c|}
\hline Field site & Map no. & Subsample no. & Sample mtl & Cs & $\mathrm{Cu}$ & $\mathrm{Fe}$ & $\mathrm{Ga}$ & $\mathrm{Ge}$ & $\mathrm{Hf}$ & $\ln$ & $\mathrm{K}$ & $\mathrm{La}$ & $\mathrm{Li}$ & $\mathrm{Mg}$ \\
\hline & & & Units- & $\mathrm{ppm}$ & ppm & $\%$ & ppm & $\mathrm{ppm}$ & ppm & ppm & $\%$ & ppm & $\mathrm{ppm}$ & $\%$ \\
\hline $21 \mathrm{CCO} 3$ & 3 & 21CC03SA & Bulk & 1.25 & 29.8 & 2.77 & 12.15 & 0.25 & 0.8 & 0.04 & 0.87 & 13.5 & 20 & 0.93 \\
\hline 21CC04 & 4 & 21CC04SA & Bulk & 0.9 & 35.6 & 3.11 & 11.45 & 0.25 & 0.8 & 0.035 & 0.81 & 12.5 & 17.2 & 1.15 \\
\hline 21CC05 & 5 & $21 \mathrm{CC} 05 \mathrm{~S}$ & Bedrock & 0.9 & 19.2 & 1.68 & 7 & 0.1 & 0.9 & 0.02 & 0.68 & 8.5 & 19.6 & 0.53 \\
\hline 21CC06 & 6 & $21 \mathrm{CCO} 6 \mathrm{~S}$ & Bedrock & 0.7 & 8.8 & 0.88 & 17.85 & 0.15 & 0.6 & 0.005 & 3.71 & 8 & 9.8 & 0.79 \\
\hline 21CC07 & 7 & $21 \mathrm{CCO} 7 \mathrm{~S}$ & Bulk & 0.85 & 23 & 2.09 & 10.5 & 0.2 & 0.6 & 0.03 & 0.82 & 8 & 12.8 & 0.65 \\
\hline \multirow[t]{2}{*}{$21 C C 08$} & 8 & $21 \mathrm{CC} 08 \mathrm{SC}$ & $>2 \mathrm{~mm}$ & 0.8 & 22.2 & 2.43 & 10.4 & 0.15 & 0.8 & 0.03 & 0.74 & 8 & 14 & 0.94 \\
\hline & & 21CC08SF1 & $<2 \mathrm{~mm}$ & 1.05 & 22.8 & 1.91 & 10.95 & 0.15 & 0.5 & 0.02 & 1.02 & 9.5 & 14.2 & 0.64 \\
\hline 21CC09 & 9 & 21Cco9s & Bedrock & 3.5 & 13.6 & 1.49 & 15.05 & 0.2 & 3.6 & 0.025 & 1.76 & 13.5 & 23.8 & 0.3 \\
\hline $21 \mathrm{CC} 10$ & 10 & 21CC10SB1 & Bulk & 1.45 & 34 & 3.67 & 12.85 & 0.2 & 1 & 0.035 & 0.96 & 8.5 & 31 & 1.15 \\
\hline \multirow[t]{3}{*}{$21 C C 11$} & 11 & 21CC11SB1 & Bulk & 0.8 & 30.6 & 3.13 & 12.4 & 0.2 & 0.8 & 0.04 & 0.75 & 9 & 15.2 & 1.13 \\
\hline & & $21 \mathrm{CC} 11 \mathrm{SC}$ & $>2 \mathrm{~mm}$ & 0.75 & 31.2 & 3.69 & 12.95 & 0.25 & 0.9 & 0.045 & 0.64 & 6.5 & 15.8 & 1.47 \\
\hline & & $21 \mathrm{CCl} 1 \mathrm{SF}$ & $<2 \mathrm{~mm}$ & 0.9 & 30.4 & 2.1 & 10.5 & 0.2 & 0.5 & 0.03 & 1 & 16.5 & 13.2 & 0.66 \\
\hline \multirow[t]{4}{*}{$21 \mathrm{CC} 13$} & 13 & 21CC13B & Bulk & 0.85 & 85 & 3.13 & 12.4 & 0.15 & 0.5 & 0.065 & 0.68 & 4 & 38.2 & 1.97 \\
\hline & & $21 \mathrm{CC} 13 \mathrm{SC}$ & $>2 \mathrm{~mm}$ & 0.8 & 110.5 & 3.71 & 12.55 & 0.15 & 0.5 & 0.065 & 0.56 & 4 & 41.4 & 2.48 \\
\hline & & 21CC13SF1 & $<2 \mathrm{~mm}$ & 1.15 & 143.1 & 2.98 & 11.75 & 0.15 & 0.5 & 0.06 & 0.73 & 7 & 45.4 & 1.66 \\
\hline & & 21CC13ST & Bedrock & 4 & 50.2 & 2.65 & 14.1 & 0.15 & 3.6 & 0.025 & 1.97 & 14 & 22.4 & 0.3 \\
\hline \multirow[t]{3}{*}{$21 \mathrm{CC} 14$} & 14 & $21 \mathrm{CC} 14 \mathrm{SB}$ & Bulk & 1.3 & 42.8 & 3.5 & 12.75 & 0.25 & 1.2 & 0.045 & 0.71 & 13 & 24.2 & 1.32 \\
\hline & & $21 \mathrm{CC} 14 \mathrm{SC}$ & $>2 \mathrm{~mm}$ & 1.25 & 50 & 3.41 & 12.15 & 0.2 & 1.2 & 0.05 & 0.65 & 11.5 & 24.2 & 1.28 \\
\hline & & 21CC14SF1 & $<2 \mathrm{~mm}$ & 1.2 & 61.6 & 4.21 & 14.4 & 0.25 & 1.1 & 0.065 & 0.69 & 12.5 & 32.2 & 1.62 \\
\hline \multirow{3}{*}{$21 \mathrm{CC} 15$} & 15 & $21 \mathrm{CC} 15 \mathrm{CL} 1$ & Bulk & 1.65 & 57.8 & 3.54 & 16.35 & 0.2 & 1.4 & 0.07 & 0.73 & 11 & 51.8 & 1.16 \\
\hline & & $21 \mathrm{CC} 15 \mathrm{SCl}$ & Bulk & 1.05 & 27.2 & 2.43 & 10.2 & 0.2 & 0.8 & 0.035 & 0.83 & 11.5 & 25.2 & 0.73 \\
\hline & & 21CC15SF1 & Bulk & 1.05 & 28.2 & 2.4 & 10.65 & 0.2 & 0.9 & 0.04 & 1.04 & 13 & 23.2 & 0.61 \\
\hline \multirow[t]{3}{*}{ 21CC16 } & 16 & 21CC16B & Bulk & 1.15 & 39.2 & 3.22 & 13.45 & 0.3 & 1.2 & 0.04 & 0.71 & 11.5 & 35.4 & 1.11 \\
\hline & & 21CC16SC & $>2 \mathrm{~mm}$ & 0.85 & 30.4 & 3.59 & 11.35 & 0.25 & 1 & 0.04 & 0.63 & 9.5 & 28 & 1.46 \\
\hline & & $21 \mathrm{CC} 16 \mathrm{SF}$ & $<2 \mathrm{~mm}$ & 1.4 & 46.2 & 3.21 & 13.9 & 0.25 & 1.1 & 0.045 & 0.86 & 11.5 & 41.6 & 1.02 \\
\hline \multirow[t]{3}{*}{ 21CC17 } & 17 & $21 \mathrm{CC} 17 \mathrm{SB}$ & Bulk & 0.9 & 44 & 4.2 & 13.75 & 0.2 & 0.9 & 0.05 & 0.56 & 6.5 & 33.8 & 1.52 \\
\hline & & $21 \mathrm{CC} 17 \mathrm{SC}$ & $>2 \mathrm{~mm}$ & 0.85 & 37.6 & 3.59 & 12.6 & 0.25 & 0.9 & 0.06 & 0.55 & 7 & 28.4 & 1.45 \\
\hline & & 21CC17SF1 & $<2 \mathrm{~mm}$ & 1.45 & 57 & 4 & 14.75 & 0.25 & 1.1 & 0.06 & 0.74 & 8.5 & 60.8 & 1.45 \\
\hline 21CC18 & 18 & 21CC18SB1 & Bulk & 0.65 & 25.2 & 2.82 & 14.45 & 0.35 & 0.7 & 0.045 & 0.79 & 67 & 12.2 & 0.97 \\
\hline 21CC19 & 19 & 21CC19SB1 & Bulk & 1.7 & 17 & 2.08 & 14.5 & 0.15 & 0.4 & 0.025 & 1.2 & 11 & 23.2 & 0.89 \\
\hline
\end{tabular}


Table 4. Concentrations of major and minor elements in dredge tailings and sediment samples, determined by ICP-MS and ICP-AES

\begin{tabular}{|c|c|c|c|c|c|c|c|c|c|c|c|c|c|c|}
\hline Field site & Map no. & Subsample no. & Sample mtl & $\mathrm{Mn}$ & Mo & $\mathrm{Na}$ & $\mathrm{Nb}$ & $\mathrm{Ni}$ & $P$ & $\mathrm{~Pb}$ & $\mathrm{Rb}$ & $\mathrm{Re}$ & $S$ & $\mathrm{Sb}$ \\
\hline & & & Units- & ppm & ppm & $\%$ & ppm & ppm & ppm & ppm & ppm & ppm & $\%$ & ppm \\
\hline $21 \mathrm{CCO} 3$ & 3 & 21CC03SA & Bulk & 345 & 1.7 & 1.5 & 3.1 & 24.8 & 230 & 7 & 25.2 & $<0.002$ & $<0.01$ & 0.75 \\
\hline 21CC04 & 4 & 21CC04SA & Bulk & 395 & 0.95 & 1.59 & 2.3 & 20.6 & 230 & 5.5 & 17.3 & $<0.002$ & $<0.01$ & 0.75 \\
\hline 21CC05 & 5 & $21 \mathrm{CCO} 5 \mathrm{~S}$ & Bedrock & 100 & 2.1 & 1.04 & 2.4 & 19.6 & 400 & 4.5 & 23.2 & $<0.002$ & 0.03 & 0.65 \\
\hline 21CC06 & 6 & $21 \mathrm{CCO} 0 \mathrm{~S}$ & Bedrock & 115 & 1 & 1.86 & 2.3 & 2.6 & 110 & 6.5 & 65.1 & $<0.002$ & $<0.01$ & 0.1 \\
\hline 21CC07 & 7 & $21 \mathrm{CCO} 0 \mathrm{~S}$ & Bulk & 240 & 1.9 & 1.77 & 1.9 & 18.6 & 170 & 4.5 & 18.2 & $<0.002$ & 0.01 & 0.5 \\
\hline \multirow[t]{2}{*}{$21 C C 08$} & 8 & $21 \mathrm{CC} 08 \mathrm{SC}$ & $>2 \mathrm{~mm}$ & 285 & 0.85 & 1.7 & 2.4 & 20 & 280 & 5 & 20.2 & $<0.002$ & 0.01 & 0.5 \\
\hline & & 21CC08SF1 & $<2 \mathrm{~mm}$ & 255 & 2.2 & 1.64 & 2.2 & 16 & 180 & 6 & 25.8 & $<0.002$ & $<0.01$ & 0.4 \\
\hline 21CC09 & 9 & 21CCo9s & Bedrock & 330 & 2 & 2.51 & 6.2 & 5.6 & 80 & 12.5 & 46.8 & $<0.002$ & $<0.01$ & 0.8 \\
\hline $21 \mathrm{CC} 10$ & 10 & 21CC10SB1 & Bulk & 505 & 1.8 & 1.57 & 2.9 & 39 & 250 & 5.5 & 23.3 & $<0.002$ & 0.02 & 0.65 \\
\hline \multirow[t]{3}{*}{ 21CC11 } & 11 & $21 \mathrm{CC} 11 \mathrm{SB} 1$ & Bulk & 415 & 1.2 & 1.5 & 2.2 & 22.6 & 200 & 5 & 16.6 & $<0.002$ & 0.01 & 0.7 \\
\hline & & $21 \mathrm{CC} 11 \mathrm{SC}$ & $>2 \mathrm{~mm}$ & 505 & 0.95 & 1.52 & 2.2 & 33.4 & 240 & 4.5 & 14.1 & $<0.002$ & 0.01 & 0.6 \\
\hline & & $21 \mathrm{CCl} 1 \mathrm{SF}$ & $<2 \mathrm{~mm}$ & 245 & 3.5 & 1.82 & 1.5 & 15.8 & 180 & 6.5 & 22.3 & $<0.002$ & $<0.01$ & 0.6 \\
\hline \multirow[t]{4}{*}{$21 \mathrm{CC} 13$} & 13 & $21 \mathrm{CC} 13 \mathrm{~B}$ & Bulk & 400 & 2.85 & 1.61 & 1.8 & 27.2 & 10 & 31.5 & 10.3 & 0.002 & 0.37 & 1.65 \\
\hline & & $21 \mathrm{CC} 13 \mathrm{SC}$ & $>2 \mathrm{~mm}$ & 465 & 2.5 & 1.53 & 1.5 & 35 & 30 & 9.5 & 8.8 & 0.002 & 0.49 & 0.55 \\
\hline & & 21CC13SF1 & $<2 \mathrm{~mm}$ & 360 & 2.2 & 1.56 & 1.9 & 27.8 & 40 & 22.5 & 14.5 & 0.002 & 0.96 & 1 \\
\hline & & 21CC13ST & Bedrock & 325 & 2.6 & 2.32 & 6 & 7.8 & 50 & 16 & 57.1 & $<0.002$ & 0.01 & 0.9 \\
\hline \multirow[t]{3}{*}{ 21CC14 } & 14 & 21CC14SB & Bulk & 385 & 2.05 & 0.93 & 3.2 & 33 & 200 & 8 & 24.2 & $<0.002$ & $<0.01$ & 0.65 \\
\hline & & $21 \mathrm{CC} 14 \mathrm{SC}$ & $>2 \mathrm{~mm}$ & 340 & 2.05 & 0.8 & 3.1 & 34.4 & 170 & 8 & 23.8 & $<0.002$ & $<0.01$ & 0.75 \\
\hline & & 21CC14SF1 & $<2 \mathrm{~mm}$ & 550 & 1.3 & 1.23 & 2.9 & 36.2 & 190 & 12.5 & 16.2 & $<0.002$ & 0.01 & 0.65 \\
\hline \multirow[t]{3}{*}{ 21CC15 } & 15 & $21 \mathrm{CC} 15 \mathrm{CL} 1$ & Bulk & 410 & 1.4 & 1.77 & 4.9 & 32.4 & 130 & 7 & 20.4 & $<0.002$ & $<0.01$ & 0.65 \\
\hline & & $21 \mathrm{CC} 15 \mathrm{SCl}$ & Bulk & 265 & 2.45 & 1.37 & 2.2 & 18.4 & 140 & 5 & 22.1 & $<0.002$ & $<0.01$ & 0.45 \\
\hline & & 21CC15SF1 & Bulk & 370 & 1.25 & 1.59 & 2.6 & 17.2 & 100 & 6.5 & 23.7 & $<0.002$ & $<0.01$ & 0.45 \\
\hline \multirow[t]{3}{*}{ 21CC16 } & 16 & $21 \mathrm{CC} 16 \mathrm{~B}$ & Bulk & 435 & 2.05 & 1.65 & 3.4 & 30.6 & 230 & 5.5 & 21.2 & $<0.002$ & $<0.01$ & 0.6 \\
\hline & & 21CC16SC & $>2 \mathrm{~mm}$ & 480 & 2.05 & 1.67 & 2.6 & 28.6 & 220 & 4 & 16.7 & $<0.002$ & $<0.01$ & 0.55 \\
\hline & & $21 \mathrm{CCl} 16 \mathrm{SF}$ & $<2 \mathrm{~mm}$ & 550 & 1.45 & 1.71 & 3.4 & 28 & 140 & 6.5 & 22.4 & $<0.002$ & $<0.01$ & 0.6 \\
\hline \multirow[t]{3}{*}{$21 \mathrm{CC} 17$} & 17 & $21 \mathrm{CC} 17 \mathrm{SB}$ & Bulk & 495 & 1 & 1.32 & 2.2 & 35 & 210 & 6.5 & 11.4 & $<0.002$ & 0.01 & 0.6 \\
\hline & & $21 \mathrm{CC} 17 \mathrm{SC}$ & $>2 \mathrm{~mm}$ & 465 & 0.9 & 1.59 & 2.7 & 28.2 & 280 & 5 & 13.5 & $<0.002$ & 0.01 & 0.65 \\
\hline & & 21CC17SF1 & $<2 \mathrm{~mm}$ & 470 & 1.45 & 1.73 & 3.1 & 47.6 & 260 & 11 & 18.9 & $<0.002$ & 0.01 & 0.7 \\
\hline $21 \mathrm{CC} 18$ & 18 & 21CC18SB1 & Bulk & 430 & 2.95 & 2.55 & 2.4 & 18.6 & 220 & 6 & 14.9 & $<0.002$ & 0.02 & 0.4 \\
\hline 21CC19 & 19 & 21CC19SB1 & Bulk & 325 & 1.05 & 2 & 3.2 & 22 & 160 & 9 & 35.6 & $<0.002$ & $<0.01$ & 0.4 \\
\hline
\end{tabular}


Table 4. Concentrations of major and minor elements in dredge tailings and sediment samples, determined by ICP-MS and ICP-AES

\begin{tabular}{|c|c|c|c|c|c|c|c|c|c|c|c|c|c|c|}
\hline Field site & Map no. & Subsample no. & $\begin{array}{r}\text { Sample mtl } \\
\text { Units- }\end{array}$ & $\begin{array}{l}\mathrm{Se} \\
\mathrm{ppm}\end{array}$ & $\begin{array}{l}\mathrm{Sn} \\
\mathrm{ppm}\end{array}$ & $\begin{array}{c}\mathrm{Sr} \\
\mathrm{ppm}\end{array}$ & $\begin{array}{c}\mathrm{Ta} \\
\mathrm{ppm}\end{array}$ & $\begin{array}{c}\mathrm{Te} \\
\mathrm{ppm}\end{array}$ & $\begin{array}{l}\text { Th } \\
\text { ppm }\end{array}$ & $\begin{array}{l}\mathrm{Ti} \\
\%\end{array}$ & $\begin{array}{c}\mathrm{TI} \\
\mathrm{ppm}\end{array}$ & $\begin{array}{c}\mathrm{U} \\
\mathrm{ppm}\end{array}$ & $\begin{array}{c}\mathrm{V} \\
\mathrm{ppm}\end{array}$ & $\begin{array}{c}\mathrm{W} \\
\mathrm{ppm}\end{array}$ \\
\hline $21 \mathrm{CCO} 3$ & 3 & 21CC03SA & Bulk & $<1$ & 0.6 & 153.5 & 0.35 & 0.05 & 3.8 & 0.2 & 0.18 & 0.9 & 113 & 1.1 \\
\hline 21CC04 & 4 & 21CCO4SA & Bulk & $<1$ & 0.4 & 144.5 & 0.2 & 0.05 & 2.6 & 0.21 & 0.16 & 0.7 & 122 & 1 \\
\hline 21CC05 & 5 & 21CC05S & Bedrock & $<1$ & 0.2 & 29 & 0.2 & 0.05 & 2 & 0.11 & 0.16 & 1.2 & 81 & 0.4 \\
\hline 21CC06 & 6 & $21 \mathrm{CCO} 0 \mathrm{~S}$ & Bedrock & $<1$ & 1 & 243 & 0.2 & 0.05 & 2.4 & 0.08 & 0.3 & 0.5 & 17 & 2.7 \\
\hline 21CC07 & 7 & $21 \mathrm{CCO} 7 \mathrm{~S}$ & Bulk & $<1$ & 0.8 & 163 & 0.2 & $<0.05$ & 2.2 & 0.15 & 0.12 & 0.6 & 74 & 0.7 \\
\hline \multirow[t]{2}{*}{$21 C C 08$} & 8 & $21 \mathrm{CCO} 8 \mathrm{SC}$ & $>2 \mathrm{~mm}$ & $<1$ & 0.4 & 130 & 0.2 & 0.05 & 2.4 & 0.17 & 0.14 & 0.9 & 104 & 0.6 \\
\hline & & 21CC08SF1 & $<2 \mathrm{~mm}$ & $<1$ & 0.4 & 211 & 0.2 & 0.05 & 2.8 & 0.14 & 0.14 & 0.7 & 66 & 0.6 \\
\hline 21CC09 & 9 & 21CCo9s & Bedrock & $<1$ & 0.8 & 208 & 0.6 & $<0.05$ & 8 & 0.2 & 0.36 & 2.8 & 40 & 1.5 \\
\hline 21CC10 & 10 & 21CC10SB1 & Bulk & $<1$ & 0.4 & 209 & 0.25 & 0.1 & 3 & 0.24 & 0.18 & 0.8 & 141 & 1.7 \\
\hline \multirow[t]{3}{*}{ 21CC11 } & 11 & $21 C C 11 S B 1$ & Bulk & $<1$ & 0.4 & 128 & 0.2 & 0.1 & 2.4 & 0.2 & 0.14 & 0.7 & 138 & 0.6 \\
\hline & & $21 \mathrm{CCl} 1 \mathrm{SC}$ & $>2 \mathrm{~mm}$ & $<1$ & 0.6 & 140 & 0.2 & 0.05 & 2 & 0.22 & 0.12 & 0.7 & 150 & 0.7 \\
\hline & & $21 \mathrm{CCl} 1 \mathrm{SF}$ & $<2 \mathrm{~mm}$ & $<1$ & 0.2 & 235 & 0.15 & 0.2 & 3.2 & 0.13 & 0.18 & 0.6 & 77 & 0.5 \\
\hline \multirow[t]{4}{*}{ 21CC13 } & 13 & $21 \mathrm{CC} 13 \mathrm{~B}$ & Bulk & $<1$ & 0.6 & 155.5 & 0.15 & 0.45 & 0.8 & 0.21 & 0.08 & 0.4 & 159 & 4.4 \\
\hline & & 21CC13SC & $>2 \mathrm{~mm}$ & $<1$ & 0.6 & 160 & 0.15 & 0.4 & 0.8 & 0.21 & 0.08 & 0.4 & 161 & 4.3 \\
\hline & & 21CC13SF1 & $<2 \mathrm{~mm}$ & $<1$ & 0.6 & 280 & 0.15 & 0.45 & 1 & 0.19 & 0.1 & 0.5 & 149 & 4.8 \\
\hline & & 21CC13ST & Bedrock & $<1$ & 0.8 & 174.5 & 0.6 & $<0.05$ & 9 & 0.16 & 0.48 & 3.5 & 35 & 2.5 \\
\hline \multirow[t]{3}{*}{ 21CC14 } & 14 & $21 \mathrm{CC} 14 \mathrm{SB}$ & Bulk & $<1$ & 0.6 & 75.6 & 0.25 & 0.05 & 3.2 & 0.23 & 0.18 & 1.2 & 160 & 0.8 \\
\hline & & $21 \mathrm{CC} 14 \mathrm{SC}$ & $>2 \mathrm{~mm}$ & $<1$ & 0.6 & 73 & 0.25 & 0.05 & 3.4 & 0.22 & 0.18 & 1.2 & 166 & 0.9 \\
\hline & & 21CC14SF1 & $<2 \mathrm{~mm}$ & $<1$ & 0.8 & 109.5 & 0.3 & 0.15 & 2.6 & 0.27 & 0.16 & 1 & 159 & 1.3 \\
\hline \multirow[t]{3}{*}{ 21CC15 } & 15 & $21 \mathrm{CC} 15 \mathrm{CL} 1$ & Bulk & $<1$ & 0.8 & 139 & 0.45 & 0.1 & 3.8 & 0.39 & 0.18 & 1.4 & 145 & 1.9 \\
\hline & & $21 \mathrm{CC} 15 \mathrm{SCl}$ & Bulk & $<1$ & 0.6 & 136 & 0.2 & 0.05 & 2.6 & 0.16 & 0.14 & 0.8 & 107 & 0.7 \\
\hline & & 21CC15SF1 & Bulk & $<1$ & 0.4 & 151 & 0.2 & 0.05 & 3 & 0.21 & 0.14 & 0.8 & 98 & 0.8 \\
\hline \multirow[t]{3}{*}{ 21CC16 } & 16 & 21CC16B & Bulk & $<1$ & 0.6 & 130.5 & 0.3 & 0.1 & 3.2 & 0.24 & 0.16 & 1.1 & 126 & 0.9 \\
\hline & & 21CC16SC & $>2 \mathrm{~mm}$ & $<1$ & 0.4 & 79.7 & 0.2 & 0.05 & 2.4 & 0.25 & 0.12 & 0.9 & 146 & 0.9 \\
\hline & & $21 \mathrm{CCl} 16 \mathrm{SF}$ & $<2 \mathrm{~mm}$ & $<1$ & 0.6 & 148.5 & 0.3 & 0.1 & 3.2 & 0.27 & 0.18 & 1.1 & 125 & 1.3 \\
\hline \multirow[t]{3}{*}{$21 \mathrm{CC} 17$} & 17 & $21 \mathrm{CC} 17 \mathrm{SB}$ & Bulk & $<1$ & 0.4 & 106.5 & 0.2 & 0.1 & 1.8 & 0.24 & 0.1 & 0.7 & 161 & 0.8 \\
\hline & & $21 \mathrm{CC} 17 \mathrm{SC}$ & $>2 \mathrm{~mm}$ & $<1$ & 0.6 & 112.5 & 0.2 & 0.05 & 2 & 0.23 & 0.1 & 0.7 & 153 & 1.1 \\
\hline & & 21CC17SF1 & $<2 \mathrm{~mm}$ & $<1$ & 0.6 & 129.5 & 0.25 & 0.15 & 2.4 & 0.28 & 0.14 & 1 & 148 & 1.1 \\
\hline 21CC18 & 18 & 21CC18SB1 & Bulk & $<1$ & 1.6 & 207 & 0.25 & 0.05 & 8.6 & 0.19 & 0.1 & 1.2 & 93 & 0.9 \\
\hline 21CC19 & 19 & 21CC19SB1 & Bulk & $<1$ & 0.6 & 288 & 0.3 & $<0.05$ & 4 & 0.19 & 0.24 & 0.8 & 60 & 0.7 \\
\hline
\end{tabular}


Table 4. Concentrations of major and minor elements in dredge tailings and sediment samples, determined by ICP-MS and ICP-AES

\begin{tabular}{|c|c|c|c|c|c|c|}
\hline Field site & Map no. & Subsample no. & $\begin{array}{c}\text { Sample mtl } \\
\text { Units- }\end{array}$ & $\begin{array}{c}\mathrm{Y} \\
\mathrm{ppm}\end{array}$ & $\begin{array}{c}\mathrm{Zn} \\
\mathrm{ppm}\end{array}$ & $\begin{array}{c}\mathrm{Zr} \\
\mathrm{ppm}\end{array}$ \\
\hline $21 C \mathrm{CO} 3$ & 3 & 21CC03SA & Bulk & 8.7 & 58 & 26.5 \\
\hline 21CC04 & 4 & $21 \mathrm{CC} 04 \mathrm{SA}$ & Bulk & 7.6 & 58 & 23.5 \\
\hline 21CC05 & 5 & 21CC05S & Bedrock & 6.3 & 42 & 34 \\
\hline 21CC06 & 6 & $21 \mathrm{CCO} 0 \mathrm{~S}$ & Bedrock & 5.5 & 12 & 11.5 \\
\hline 21CC07 & 7 & $21 \mathrm{CC} 07 \mathrm{~S}$ & Bulk & 8.1 & 38 & 16 \\
\hline \multirow[t]{2}{*}{$21 C C 08$} & 8 & $21 \mathrm{CC} 08 \mathrm{SC}$ & $>2 \mathrm{~mm}$ & 7.8 & 44 & 26 \\
\hline & & 21CC08SF1 & $<2 \mathrm{~mm}$ & 5.3 & 40 & 15 \\
\hline 21CC09 & 9 & 21Cco9s & Bedrock & 8.4 & 44 & 126 \\
\hline 21CC10 & 10 & 21CC10SB1 & Bulk & 8.1 & 64 & 30.5 \\
\hline \multirow[t]{3}{*}{$21 C C 11$} & 11 & 21CC11SB1 & Bulk & 7.4 & 56 & 25 \\
\hline & & $21 \mathrm{CC} 11 \mathrm{SC}$ & $>2 \mathrm{~mm}$ & 9.3 & 58 & 29 \\
\hline & & $21 C C 11 S F$ & $<2 \mathrm{~mm}$ & 5.4 & 42 & 15.5 \\
\hline \multirow[t]{4}{*}{ 21CC13 } & 13 & $21 \mathrm{CC} 13 \mathrm{~B}$ & Bulk & 6.4 & 50 & 15.5 \\
\hline & & $21 \mathrm{CC} 13 \mathrm{SC}$ & $>2 \mathrm{~mm}$ & 7.9 & 60 & 14.5 \\
\hline & & 21CC13SF1 & $<2 \mathrm{~mm}$ & 9 & 62 & 14.5 \\
\hline & & 21CC13ST & Bedrock & 8.5 & 64 & 148.5 \\
\hline \multirow[t]{3}{*}{ 21CC14 } & 14 & $21 \mathrm{CC} 14 \mathrm{SB}$ & Bulk & 10.6 & 62 & 44 \\
\hline & & $21 \mathrm{CC} 14 \mathrm{SC}$ & $>2 \mathrm{~mm}$ & 9.2 & 64 & 47 \\
\hline & & 21CC14SF1 & $<2 \mathrm{~mm}$ & 12.4 & 70 & 36.5 \\
\hline \multirow[t]{3}{*}{ 21CC15 } & 15 & 21CC15CL1 & Bulk & 10.8 & 66 & 47 \\
\hline & & $21 \mathrm{CC} 15 \mathrm{SC} 1$ & Bulk & 6.4 & 42 & 27.5 \\
\hline & & 21CC15SF1 & Bulk & 7 & 40 & 29.5 \\
\hline \multirow[t]{3}{*}{ 21CC16 } & 16 & $21 \mathrm{CC} 16 \mathrm{~B}$ & Bulk & 10 & 54 & 39.5 \\
\hline & & $21 \mathrm{CC} 16 \mathrm{SC}$ & $>2 \mathrm{~mm}$ & 9.5 & 56 & 30.5 \\
\hline & & 21CC16SF & $<2 \mathrm{~mm}$ & 9.3 & 56 & 36.5 \\
\hline \multirow[t]{3}{*}{ 21CC17 } & 17 & $21 \mathrm{CC} 17 \mathrm{SB}$ & Bulk & 9.1 & 62 & 29 \\
\hline & & $21 \mathrm{CC} 17 \mathrm{SC}$ & $>2 \mathrm{~mm}$ & 9.2 & 52 & 31.5 \\
\hline & & 21CC17SF1 & $<2 \mathrm{~mm}$ & 11.6 & 70 & 35 \\
\hline 21CC18 & 18 & $21 \mathrm{CC} 18 \mathrm{SB} 1$ & Bulk & 13.1 & 52 & 15.5 \\
\hline 21CC19 & 19 & 21CC19SB1 & Bulk & 5.5 & 48 & 8.5 \\
\hline
\end{tabular}


Table 5. Field parameters for water sample sites and concentrations of major anions, mercury, and methylmercury in waters

\begin{tabular}{|c|c|c|c|c|c|c|c|c|c|}
\hline $\begin{array}{l}\text { Field site } \\
\text { Units- }\end{array}$ & Date & $\begin{array}{c}\mathrm{pH} \\
\mathrm{pH} \text { units }\end{array}$ & $\begin{array}{c}\text { Temperature } \\
{ }^{\circ} \mathrm{C}\end{array}$ & $\begin{array}{c}\text { Conductivity } \\
\mu S\end{array}$ & $\begin{array}{c}\text { Alkalinity } \\
\text { ppm, as } \mathrm{CaCO} 3\end{array}$ & $\begin{array}{c}\text { Total Hg } \\
\text { ng/L }\end{array}$ & $\begin{array}{c}\text { Total Hg } \\
\text { ng/L }\end{array}$ & $\begin{array}{c}\text { Methyl Hg } \\
\text { ng/L }\end{array}$ & $\begin{array}{c}\text { Methyl Hg } \\
\text { ng/L }\end{array}$ \\
\hline 21CC1 & $8 / 27 / 01$ & 8.18 & 35.3 & 129.4 & 64 & 2.95 & 0.85 & 0.087 & 0.033 \\
\hline $21 \mathrm{CC} 2$ & 8/27/01 & 6.93 & 31.9 & 206 & 73 & 7.79 & 0.92 & 0.454 & 0.107 \\
\hline $21 C C 3$ & 8/28/01 & 6.62 & 24.0 & 145.5 & 67 & 3.54 & 0.81 & 0.235 & 0.039 \\
\hline $21 \mathrm{CC} 7$ & 8/28/01 & 6.65 & 23.8 & 220 & 83 & 9.98 & 3.96 & 4.730 & 2.280 \\
\hline 21CC10 & 8/28/01 & 6.92 & 20.3 & 1320 & 97 & 50.7 & 2.94 & 0.061 & 0.042 \\
\hline $21 \mathrm{CC} 18$ & $8 / 29 / 01$ & 7.33 & 18.3 & 69.2 & 40 & 1.55 & 0.55 & 0.027 & 0.018 \\
\hline \multicolumn{10}{|c|}{${ }^{*}$ Not determined; $\mathrm{pH}$ of subsample measured in laboratory was 4.17} \\
\hline & & & & & & & & & \\
\hline
\end{tabular}


Table 5. Field parameters for water sample sites and concentrations of major anions, mercury, and methylmercury in waters

\begin{tabular}{|c|c|c|c|c|}
\hline Field site & Chloride (Cl) & Fluoride (F) & Sulfate (SO4) & Nitrate (NO3) \\
\hline Units- & ppm & ppm & ppm & ppm \\
\hline Subsample- & Filtered & Filtered & Filtered & Filtered \\
\hline 21CC1 & 1.7 & 0.09 & 1.8 & $<0.08$ \\
\hline 21CC2 & 13 & 1.1 & 13 & $<0.08$ \\
\hline $21 \mathrm{CC} 3$ & 5.1 & 0.2 & $<1.6$ & $<0.08$ \\
\hline $21 \mathrm{CC} 7$ & 8.8 & 0.2 & 3.5 & $<0.08$ \\
\hline 21CC10 & 260 & 0.7 & 24 & 0.9 \\
\hline $21 \mathrm{CC} 11$ & 4.3 & 0.1 & 1.9 & $<0.08$ \\
\hline $21 \mathrm{CC} 12$ & 13000 & $<0.08$ & 2.8 & $<0.08$ \\
\hline 21CC18 & 5.1 & 0.2 & $<1.6$ & $<0.08$ \\
\hline \multicolumn{5}{|l|}{ *Not determined } \\
\hline & & & & \\
\hline & & & & \\
\hline
\end{tabular}


Table 6. Concentrations of major and minor cations in waters, determined by ICP-MS and ICP-AES

\begin{tabular}{|c|c|c|c|c|c|c|c|c|c|c|c|c|c|c|}
\hline \multicolumn{15}{|c|}{ CATION CONCENTRATIONS IN FILTERED WATERS } \\
\hline Field site & Subsample no. & $\mathrm{Ag}$ & Al & As & B & $\mathrm{Ba}$ & $\mathrm{Be}$ & $\mathbf{B i}$ & $\mathbf{C a}$ & Cd & $\mathrm{Ce}$ & Co & $\mathrm{Cr}$ & Cs \\
\hline & Units- & $\mu \mathrm{g} / \mathrm{L}$ & $\mu \mathrm{g} / \mathrm{L}$ & $\mu \mathrm{g} / \mathrm{L}$ & $\mu \mathrm{g} / \mathrm{L}$ & $\mu \mathrm{g} / \mathrm{L}$ & $\mu \mathrm{g} / \mathrm{L}$ & $\mu \mathrm{g} / \mathrm{L}$ & $\mathrm{mg} / \mathrm{L}$ & $\mu \mathrm{g} / \mathrm{L}$ & $\mu \mathrm{g} / \mathrm{L}$ & $\mu \mathrm{g} / \mathrm{L}$ & $\mu \mathrm{g} / \mathrm{L}$ & $\mu \mathrm{g} / \mathrm{L}$ \\
\hline & Method- & ICP-MS & ICP-MS & ICP-MS & ICP-AES & ICP-AES & ICP-MS & ICP-MS & ICP-AES & ICP-MS & ICP-MS & ICP-MS & ICP-MS & ICP-MS \\
\hline $21 \mathrm{CC} 1$ & $21 \mathrm{CC} 1 \mathrm{WB}$ & $<3$ & 7.98 & 2 & 8 & 9.6 & $<0.05$ & 0.03 & 11 & $<0.02$ & 0.01 & 0.11 & $<1$ & $<0.01$ \\
\hline 21CC2 & $21 \mathrm{CC} 2 \mathrm{WB}$ & $<3$ & 1.44 & 2 & 13 & 22 & $<0.05$ & 0.02 & 21 & $<0.02$ & $<0.01$ & 0.05 & $<1$ & $<0.01$ \\
\hline $21 \mathrm{CC} 3$ & $21 \mathrm{CC} 3 W B$ & $<3$ & 1.9 & 2 & 7.9 & 26 & $<0.05$ & 0.01 & 12 & $<0.02$ & $<0.01$ & 0.12 & $<1$ & $<0.01$ \\
\hline $21 \mathrm{CC} 7$ & 21CC7B & $<3$ & 5.48 & 11.9 & 18 & 34 & $<0.05$ & 0.01 & 19 & $<0.02$ & 0.14 & 0.7 & $<1$ & $<0.01$ \\
\hline 21CC10 & $21 \mathrm{CC} 10 \mathrm{~B}$ & $<3$ & 1.32 & 3 & 86 & 220 & $<0.05$ & 0.01 & 110 & $<0.02$ & $<0.01$ & 0.09 & $<1$ & $<0.01$ \\
\hline 21CC11 & 21CC11B & $<3$ & 1.83 & $<1$ & 10 & 8.4 & $<0.05$ & 0.006 & 6.4 & $<0.02$ & $<0.01$ & $<0.02$ & $<1$ & $<0.01$ \\
\hline 21CC12 & 21CC12B1 & $<3$ & 25.4 & 24.6 & 2600 & 2500 & $<0.05$ & 0.18 & 2600 & 0.05 & 1.98 & 11.6 & $<1$ & 0.28 \\
\hline 21CC12 & 21CC12B2 & $<3$ & 24.5 & 26.5 & 2600 & 2500 & $<0.05$ & 0.07 & 3000 & 0.04 & 1.87 & 11.3 & $<1$ & 0.26 \\
\hline $21 \mathrm{CC} 18$ & 21CC18WB1 & $<3$ & 1.89 & $<1$ & 35 & 8.6 & $<0.05$ & $<0.005$ & 7.4 & $<0.02$ & $<0.01$ & 0.02 & $<1$ & $<0.01$ \\
\hline $21 \mathrm{CC} 18$ & 21CC18WB2 & $<3$ & 2.38 & $<1$ & 20 & 7.4 & $<0.05$ & $<0.005$ & 6 & $<0.02$ & $<0.01$ & 0.02 & $<1$ & $<0.01$ \\
\hline \multicolumn{15}{|c|}{ CATION CONCENTRATIONS IN UNFILTERED WATERS } \\
\hline \multirow[t]{3}{*}{ Field site } & Subsample no. & $\mathrm{Ag}$ & Al & As & B & $\mathrm{Ba}$ & $\mathrm{Be}$ & $\mathbf{B i}$ & $\mathrm{Ca}$ & Cd & $\mathrm{Ce}$ & Co & $\mathrm{Cr}$ & Cs \\
\hline & Units- & $\mu \mathrm{g} / \mathrm{L}$ & $\mu \mathrm{g} / \mathrm{L}$ & $\mu \mathrm{g} / \mathrm{L}$ & $\mu \mathrm{g} / \mathrm{L}$ & $\mu \mathrm{g} / \mathrm{L}$ & $\mu \mathrm{g} / \mathrm{L}$ & $\mu \mathrm{g} / \mathrm{L}$ & $\mathrm{mg} / \mathrm{L}$ & $\mu \mathrm{g} / \mathrm{L}$ & $\mu \mathrm{g} / \mathrm{L}$ & $\mu \mathrm{g} / \mathrm{L}$ & $\mu \mathrm{g} / \mathrm{L}$ & $\mu \mathrm{g} / \mathrm{L}$ \\
\hline & Method- & ICP-MS & ICP-MS & ICP-MS & ICP-AES & ICP-AES & ICP-MS & ICP-MS & ICP-AES & ICP-MS & ICP-MS & ICP-MS & ICP-MS & ICP-MS \\
\hline $21 \mathrm{CC} 3$ & $21 \mathrm{CC} 3 W \mathrm{C}$ & $<3$ & 252 & 3.5 & 11 & 31 & $<0.05$ & $<0.005$ & 12 & $<0.02$ & 0.46 & 0.37 & $<1$ & 0.02 \\
\hline 21CC7 & $21 \mathrm{CC} 7 \mathrm{C}$ & $<3$ & 30.5 & 13 & 22 & 36 & $<0.05$ & $<0.005$ & 20 & $<0.02$ & 0.23 & 0.76 & $<1$ & $<0.01$ \\
\hline 21CC10 & $21 \mathrm{CC} 10 \mathrm{C}$ & $<3$ & 3.7 & 3 & 85 & 210 & $<0.05$ & $<0.005$ & 100 & $<0.02$ & $<0.01$ & 0.1 & $<1$ & $<0.01$ \\
\hline 21CC11 & $21 \mathrm{CC} 11 \mathrm{C}$ & $<3$ & 6.74 & $<1$ & 10 & 8.1 & $<0.05$ & $<0.005$ & 5.9 & $<0.02$ & 0.01 & 0.02 & $<1$ & $<0.01$ \\
\hline 21CC18 & 21CC18WC1 & $<3$ & 5.91 & $<1$ & 11 & 6.9 & $<0.05$ & $<0.005$ & 5.2 & $<0.02$ & $<0.01$ & 0.03 & $<1$ & $<0.01$ \\
\hline 21CC18 & 21CC18WC2 & $<3$ & 6.66 & $<1$ & 11 & 6.9 & $<0.05$ & $<0.005$ & 5.2 & $<0.02$ & 0.01 & 0.03 & $<1$ & $<0.01$ \\
\hline
\end{tabular}


Table 6. Concentrations of major and minor cations in waters, determined by ICP-MS and ICP-AES

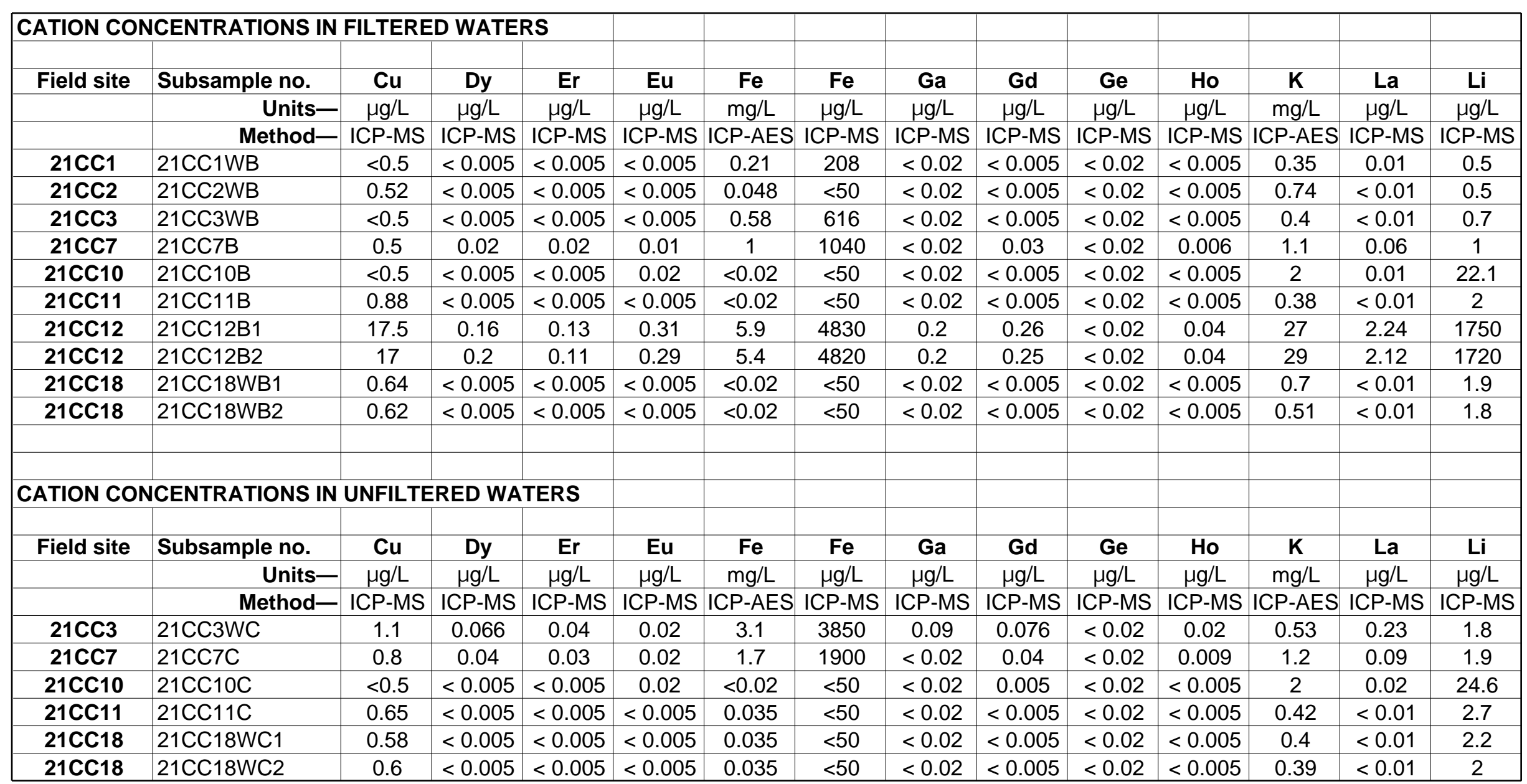


Table 6. Concentrations of major and minor cations in waters, determined by ICP-MS and ICP-AES

\begin{tabular}{|c|c|c|c|c|c|c|c|c|c|c|c|c|c|c|}
\hline \multicolumn{15}{|c|}{ CATION CONCENTRATIONS IN FILTERED WATERS } \\
\hline Field site & $\begin{array}{r}\text { Subsample no. } \\
\text { Units- } \\
\text { Method- }\end{array}$ & $\begin{array}{c}\text { Lu } \\
\mu \mathrm{g} / \mathrm{L} \\
\text { ICP-MS }\end{array}$ & $\begin{array}{c}\mathbf{M g} \\
\mathrm{mg} / \mathrm{L} \\
\text { ICP-AES }\end{array}$ & $\begin{array}{c}\text { Mn } \\
\mu \mathrm{g} / \mathrm{L} \\
\text { ICP-MS }\end{array}$ & $\begin{array}{c}\text { Mo } \\
\mu g / L \\
\text { ICP-MS }\end{array}$ & $\begin{array}{c}\mathrm{Na} \\
\mathrm{mg} / \mathrm{L} \\
\text { ICP-AES }\end{array}$ & $\begin{array}{c}\text { Nb } \\
\mu g / L \\
\text { ICP-MS }\end{array}$ & $\begin{array}{c}\text { Nd } \\
\mu g / L \\
\text { ICP-MS }\end{array}$ & $\begin{array}{c}\mathbf{N i} \\
\mu \mathrm{g} / \mathrm{L} \\
\text { ICP-MS }\end{array}$ & $\begin{array}{c}\mathbf{P} \\
\mathrm{mg} / \mathrm{L} \\
\text { ICP-MS }\end{array}$ & $\begin{array}{c}\mathbf{P b} \\
\mu \mathrm{g} / \mathrm{L} \\
\text { ICP-MS }\end{array}$ & $\begin{array}{c}\mathbf{P r} \\
\mu g / L \\
\text { ICP-MS }\end{array}$ & $\begin{array}{c}\mathbf{R b} \\
\mu \mathrm{g} / \mathrm{L} \\
\text { ICP-MS }\end{array}$ & $\begin{array}{c}\text { Sb } \\
\mu \mathrm{g} / \mathrm{L} \\
\text { ICP-MS }\end{array}$ \\
\hline $21 \mathrm{CC} 1$ & 21CC1WB & $<0.1$ & 5.6 & 9.6 & 0.2 & 7 & 0.03 & $<0.01$ & 0.5 & $<0.01$ & $<0.05$ & $<0.01$ & 0.73 & $<0.1$ \\
\hline $21 \mathrm{CC} 2$ & $21 \mathrm{CC} 2 \mathrm{WB}$ & $<0.1$ & 5.4 & 3.5 & 0.72 & 13 & 0.02 & $<0.01$ & 0.6 & $<0.01$ & $<0.05$ & $<0.01$ & 0.3 & 0.2 \\
\hline $21 \mathrm{CC} 3$ & 21CC3WB & $<0.1$ & 6 & 225 & $<0.2$ & 7.1 & 0.02 & $<0.01$ & 0.4 & $<0.01$ & $<0.05$ & $<0.01$ & 0.61 & $<0.1$ \\
\hline $21 C C 7$ & 21CC7B & $<0.1$ & 6.1 & 619 & 0.63 & 8.9 & 0.02 & 0.09 & 1.6 & 0.03 & 0.06 & 0.02 & 1 & $<0.1$ \\
\hline 21CC10 & $21 \mathrm{CC} 10 \mathrm{~B}$ & $<0.1$ & 3.6 & 3.1 & 0.56 & 120 & 0.02 & 0.02 & 2.2 & 0.1 & $<0.05$ & $<0.01$ & 1.24 & $<0.1$ \\
\hline 21CC11 & 21CC11B & $<0.1$ & 5.8 & 2.5 & $<0.2$ & 3.4 & $<0.02$ & $<0.01$ & 1.1 & $<0.01$ & $<0.05$ & $<0.01$ & 0.31 & $<0.1$ \\
\hline 21CC12 & 21CC12B1 & $<0.1$ & 40 & 6140 & 1.62 & 5500 & 0.06 & 0.84 & 61.7 & $<0.01$ & 0.75 & 0.19 & 41.9 & 0.3 \\
\hline 21CC12 & 21CC12B2 & $<0.1$ & 35 & 6130 & 1.66 & 5600 & 0.1 & 0.77 & 57.4 & $<0.01$ & 0.72 & 0.2 & 42 & 0.26 \\
\hline 21CC18 & 21CC18WB1 & $<0.1$ & 6.2 & 5.3 & $<0.2$ & 6.4 & $<0.02$ & $<0.01$ & 1.8 & $<0.01$ & $<0.05$ & $<0.01$ & 0.31 & $<0.1$ \\
\hline $21 \mathrm{CC} 18$ & 21CC18WB2 & $<0.1$ & 6.1 & 5 & $<0.2$ & 3.8 & $<0.02$ & $<0.01$ & 1.8 & $<0.01$ & $<0.05$ & $<0.01$ & 0.31 & $<0.1$ \\
\hline & & & & & & & & & & & & & & \\
\hline \multicolumn{15}{|c|}{ CATION CONCENTRATIONS IN UNFILTERED WATERS } \\
\hline Field site & Subsample no. & Lu & Mg & Mn & Mo & $\mathrm{Na}$ & $\mathrm{Nb}$ & Nd & $\mathbf{N i}$ & $\mathbf{P}$ & $\mathbf{P b}$ & $\operatorname{Pr}$ & $\mathbf{R b}$ & Sb \\
\hline & Units- & $\mu \mathrm{g} / \mathrm{L}$ & $\mathrm{mg} / \mathrm{L}$ & $\mu \mathrm{g} / \mathrm{L}$ & $\mu \mathrm{g} / \mathrm{L}$ & $\mathrm{mg} / \mathrm{L}$ & $\mu \mathrm{g} / \mathrm{L}$ & $\mu \mathrm{g} / \mathrm{L}$ & $\mu \mathrm{g} / \mathrm{L}$ & $\mathrm{mg} / \mathrm{L}$ & $\mu \mathrm{g} / \mathrm{L}$ & $\mu \mathrm{g} / \mathrm{L}$ & $\mu \mathrm{g} / \mathrm{L}$ & $\mu \mathrm{g} / \mathrm{L}$ \\
\hline & Method- & ICP-MS & ICP-AES & ICP-MS & ICP-MS & ICP-AES & ICP-MS & ICP-MS & ICP-MS & ICP-MS & ICP-MS & ICP-MS & ICP-MS & ICP-MS \\
\hline $21 \mathrm{CC} 3$ & 21CC3WC & $<0.1$ & 6 & 291 & $<0.2$ & 7.2 & $<0.02$ & 0.31 & 0.8 & 0.04 & 0.2 & 0.07 & 0.92 & $<0.1$ \\
\hline $21 \mathrm{CC} 7$ & 21CC7C & $<0.1$ & 6.3 & 699 & 0.54 & 9.4 & $<0.02$ & 0.12 & 1.7 & 0.05 & 0.09 & 0.03 & 0.99 & $<0.1$ \\
\hline 21CC10 & $21 \mathrm{CC} 10 \mathrm{C}$ & $<0.1$ & 3.5 & 3.7 & 0.53 & 110 & $<0.02$ & 0.02 & 2.2 & 0.1 & $<0.05$ & $<0.01$ & 1.28 & $<0.1$ \\
\hline 21CC11 & $21 \mathrm{CC} 11 \mathrm{C}$ & $<0.1$ & 5.3 & 4.5 & $<0.2$ & 3.3 & $<0.02$ & $<0.01$ & 1.2 & $<0.01$ & $<0.05$ & $<0.01$ & 0.33 & $<0.1$ \\
\hline 21CC18 & 21CC18WC1 & $<0.1$ & 6.2 & 7.1 & $<0.2$ & 2.4 & $<0.02$ & 0.01 & 1.8 & $<0.01$ & $<0.05$ & $<0.01$ & 0.32 & $<0.1$ \\
\hline 21CC18 & 21CC18WC2 & $<0.1$ & 6.1 & 7.3 & $<0.2$ & 2.3 & $<0.02$ & 0.01 & 1.9 & $<0.01$ & $<0.05$ & $<0.01$ & 0.31 & $<0.1$ \\
\hline
\end{tabular}


Table 6. Concentrations of major and minor cations in waters, determined by ICP-MS and ICP-AES

\begin{tabular}{|c|c|c|c|c|c|c|c|c|c|c|c|c|c|c|}
\hline \multicolumn{15}{|c|}{ CATION CONCENTRATIONS IN FILTERED WATERS } \\
\hline Field site & $\begin{array}{r}\text { Subsample no. } \\
\text { Units- } \\
\text { Method- }\end{array}$ & $\begin{array}{c}\text { Sc } \\
\mu g / L \\
\text { ICP-MS }\end{array}$ & $\begin{array}{c}\text { Se } \\
\mu g / L \\
\text { ICP-MS }\end{array}$ & $\begin{array}{c}\mathbf{S i} \\
\mathrm{mg} / \mathrm{L} \\
\text { ICP-AES }\end{array}$ & $\begin{array}{c}\text { Sm } \\
\mu \mathrm{g} / \mathrm{L} \\
\mathrm{ICP}-\mathrm{MS}\end{array}$ & $\begin{array}{c}\mathrm{SO4} \\
\mathrm{mg} / \mathrm{L} \\
\text { ICP-MS }\end{array}$ & $\begin{array}{c}\text { Sr } \\
\mu \mathrm{g} / \mathrm{L} \\
\text { ICP-MS }\end{array}$ & $\begin{array}{c}\text { Ta } \\
\mu \mathrm{g} / \mathrm{L} \\
\text { ICP-MS }\end{array}$ & $\begin{array}{c}\text { Tb } \\
\mu g / L \\
\text { ICP-MS }\end{array}$ & $\begin{array}{c}\text { Th } \\
\mu g / L \\
\text { ICP-MS }\end{array}$ & $\begin{array}{c}\text { Ti } \\
\mu \mathrm{g} / \mathrm{L} \\
\text { ICP-MS }\end{array}$ & $\begin{array}{c}\text { TI } \\
\mu \mathrm{g} / \mathrm{L} \\
\text { ICP-MS }\end{array}$ & $\begin{array}{c}\text { Tm } \\
\mu \mathrm{g} / \mathrm{L} \\
\text { ICP-MS }\end{array}$ & $\begin{array}{c}\mathbf{U} \\
\mu \mathrm{g} / \mathrm{L} \\
\text { ICP-MS }\end{array}$ \\
\hline 21CC1 & 21CC1WB & 0.6 & $<1$ & 4 & $<0.01$ & $<2$ & 102 & $<0.02$ & $<0.005$ & 0.01 & $<0.1$ & 0.08 & $<0.005$ & 0.03 \\
\hline $21 \mathrm{CC} 2$ & 21CC2WB & 1.1 & $<1$ & 5.7 & $<0.01$ & 11 & 196 & $<0.02$ & $<0.005$ & 0.01 & 0.2 & $<0.05$ & $<0.005$ & 0.008 \\
\hline $21 \mathrm{CC} 3$ & 21CC3WB & 1 & $<1$ & 5.5 & $<0.01$ & $<2$ & 111 & $<0.02$ & $<0.005$ & 0.01 & $<0.1$ & $<0.05$ & $<0.005$ & 0.005 \\
\hline $21 \mathrm{CC} 7$ & 21CC7B & 1.6 & $<1$ & 8.8 & 0.02 & $<2$ & 213 & $<0.02$ & 0.005 & 0.02 & 0.4 & $<0.05$ & $<0.005$ & 0.02 \\
\hline 21CC10 & $21 \mathrm{CC} 10 \mathrm{~B}$ & 6.9 & 2.1 & 37 & $<0.01$ & 16 & 1780 & $<0.02$ & $<0.005$ & 0.008 & 0.4 & $<0.05$ & $<0.005$ & 0.28 \\
\hline 21CC11 & 21CC11B & 0.9 & $<1$ & 6.1 & $<0.01$ & $<2$ & 35.7 & $<0.02$ & $<0.005$ & $<0.005$ & $<0.1$ & $<0.05$ & $<0.005$ & 0.03 \\
\hline 21CC12 & 21CC12B1 & 17.7 & $<1$ & 11 & 0.14 & 5 & 66800 & $<0.02$ & 0.04 & 0.03 & 7 & $<0.05$ & 0.02 & 0.01 \\
\hline 21CC12 & 21CC12B2 & 9.6 & $<1$ & 10 & 0.16 & 4 & 67400 & $<0.02$ & 0.03 & 0.03 & 5.8 & $<0.05$ & 0.02 & 0.007 \\
\hline 21CC18 & 21CC18WB1 & 1.7 & $<1$ & 6.1 & $<0.01$ & $<2$ & 27.2 & $<0.02$ & $<0.005$ & $<0.005$ & 0.5 & $<0.05$ & $<0.005$ & 0.03 \\
\hline $21 \mathrm{CC} 18$ & 21CC18WB2 & 1.4 & $<1$ & 6 & $<0.01$ & $<2$ & 25.3 & $<0.02$ & $<0.005$ & $<0.005$ & 0.4 & $<0.05$ & $<0.005$ & 0.03 \\
\hline & & & & & & & & & & & & & & \\
\hline \multicolumn{15}{|c|}{ CATION CONCENTRATIONS IN UNFILTERED WATERS } \\
\hline Field site & Subsample no. & Sc & Se & Si & Sm & SO4 & $\mathrm{Sr}$ & $\mathrm{Ta}$ & $\mathrm{Tb}$ & Th & $\mathrm{Ti}$ & TI & Tm & $\mathbf{U}$ \\
\hline & Units- & $\mu \mathrm{g} / \mathrm{L}$ & $\mu \mathrm{g} / \mathrm{L}$ & $\mathrm{mg} / \mathrm{L}$ & $\mu \mathrm{g} / \mathrm{L}$ & $\mathrm{mg} / \mathrm{L}$ & $\mu \mathrm{g} / \mathrm{L}$ & $\mu \mathrm{g} / \mathrm{L}$ & $\mu \mathrm{g} / \mathrm{L}$ & $\mu \mathrm{g} / \mathrm{L}$ & $\mu \mathrm{g} / \mathrm{L}$ & $\mu \mathrm{g} / \mathrm{L}$ & $\mu \mathrm{g} / \mathrm{L}$ & $\mu g / L$ \\
\hline & Method- & ICP-MS & ICP-MS & ICP-AES & ICP-MS & ICP-MS & ICP-MS & ICP-MS & ICP-MS & ICP-MS & ICP-MS & ICP-MS & ICP-MS & ICP-MS \\
\hline $21 \mathrm{CC} 3$ & 21Cc3WC & 1.5 & $<1$ & 5.8 & 0.06 & $<2$ & 118 & $<0.02$ & 0.01 & 0.04 & 14.3 & $<0.05$ & 0.005 & 0.02 \\
\hline $21 \mathrm{CC} 7$ & $21 C C 7 C$ & 2.2 & $<1$ & 9 & 0.04 & 2 & 226 & $<0.02$ & 0.006 & 0.02 & 1.9 & $<0.05$ & $<0.005$ & 0.02 \\
\hline 21CC10 & $21 \mathrm{CC} 10 \mathrm{C}$ & 8.8 & 1.9 & 36 & $<0.01$ & 19 & 1830 & $<0.02$ & $<0.005$ & 0.006 & 0.7 & $<0.05$ & $<0.005$ & 0.29 \\
\hline 21CC11 & $21 C C 11 C$ & 1.2 & $<1$ & 5.7 & $<0.01$ & $<2$ & 36.9 & $<0.02$ & $<0.005$ & $<0.005$ & 0.3 & $<0.05$ & $<0.005$ & 0.03 \\
\hline 21CC18 & 21CC18WC1 & 1.2 & $<1$ & 6 & $<0.01$ & $<2$ & 25 & $<0.02$ & $<0.005$ & $<0.005$ & 0.2 & $<0.05$ & $<0.005$ & 0.03 \\
\hline 21CC18 & 21CC18WC2 & 1.2 & $<1$ & 5.9 & $<0.01$ & $<2$ & 25.2 & $<0.02$ & $<0.005$ & $<0.005$ & 0.3 & $<0.05$ & $<0.005$ & 0.03 \\
\hline
\end{tabular}


Table 6. Concentrations of major and minor cations in waters, determined by ICP-MS and ICP-AES

\begin{tabular}{|c|c|c|c|c|c|c|c|}
\hline \multicolumn{8}{|c|}{ CATION CONCENTRATIONS IN FILTERED WATERS } \\
\hline Field site & $\begin{array}{r}\text { Subsample no. } \\
\text { Units- } \\
\text { Method- }\end{array}$ & $\begin{array}{c}\mathbf{V} \\
\mu \mathrm{g} / \mathrm{L} \\
\mathrm{ICP}-\mathrm{MS}\end{array}$ & $\begin{array}{c}\text { W } \\
\mu \mathrm{g} / \mathrm{L} \\
\mathrm{ICP}-\mathrm{MS}\end{array}$ & $\begin{array}{c}\mathbf{Y} \\
\mu \mathrm{g} / \mathrm{L} \\
\text { ICP-MS }\end{array}$ & $\begin{array}{c}\text { Yb } \\
\mu \mathrm{g} / \mathrm{L} \\
\text { ICP-MS }\end{array}$ & $\begin{array}{c}\mathbf{Z n} \\
\mu \mathrm{g} / \mathrm{L} \\
\mathrm{ICP}-\mathrm{MS}\end{array}$ & $\begin{array}{c}\mathrm{Zr} \\
\mu \mathrm{g} / \mathrm{L} \\
\mathrm{ICP}-\mathrm{MS}\end{array}$ \\
\hline 21CC1 & 21CC1WB & 0.9 & $<0.02$ & 0.01 & $<0.005$ & 7.2 & $<0.05$ \\
\hline 21CC2 & $21 \mathrm{CC} 2 \mathrm{WB}$ & 0.4 & $<0.02$ & $<0.01$ & $<0.005$ & 24.8 & $<0.05$ \\
\hline $21 \mathrm{CC} 3$ & $21 \mathrm{CC} 3 W B$ & 0.2 & $<0.02$ & $<0.01$ & $<0.005$ & 2 & $<0.05$ \\
\hline $21 \mathrm{CC} 7$ & 21CC7B & 1.3 & $<0.02$ & 0.2 & 0.02 & 3.8 & $<0.05$ \\
\hline $21 C C 10$ & $21 \mathrm{CC} 10 \mathrm{~B}$ & 2.3 & $<0$ & 0.09 & 0.005 & 5.6 & $<0.05$ \\
\hline 21CC11 & $21 \mathrm{CC} 11 \mathrm{~B}$ & 0. & $<0$ & 0.01 & $<0.005$ & 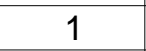 & \\
\hline 21CC12 & 21CC12B1 & $<0.1$ & $<0$ & 2.83 & & 9 & \\
\hline $21 \mathrm{CC} 12$ & 21CC12B2 & $<0.1$ & $<0$ & 2.76 & 0. & 7.5 & $<0.05$ \\
\hline $21 \mathrm{CC} 18$ & $21 \mathrm{CC} 18 \mathrm{WB}$ & & & & & 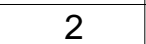 & \\
\hline $21 \mathrm{CC} 18$ & 21CC18WB2 & 0.4 & & 0.01 & $<0.005$ & 1 & $<0.05$ \\
\hline \multicolumn{8}{|c|}{ CATION CONCENTRATIONS IN UNFILTERED WATERS } \\
\hline \multirow[t]{3}{*}{ Field site } & Subsample no. & V & W & $\mathbf{Y}$ & $\mathrm{Yb}$ & $\mathrm{Zn}$ & $\mathrm{Zr}$ \\
\hline & Units- & $\mu \mathrm{g} / \mathrm{L}$ & $\mu \mathrm{g} / \mathrm{L}$ & $\mu \mathrm{g} / \mathrm{L}$ & $\mu \mathrm{g} / \mathrm{L}$ & $\mu \mathrm{g} / \mathrm{L}$ & $\mu \mathrm{g} / \mathrm{L}$ \\
\hline & Method- & ICP-MS & ICP-MS & ICP-MS & ICP-MS & ICP-MS & ICP-MS \\
\hline $21 \mathrm{CC} 3$ & 21CC3WC & 1 & $<0.02$ & 0.32 & 0.03 & 10.4 & $<0.05$ \\
\hline $21 \mathrm{CC} 7$ & $21 C C 7 C$ & 1.9 & $<0.02$ & 0.28 & 0.02 & 17.1 & $<0.05$ \\
\hline 21CC10 & $21 \mathrm{CC} 10 \mathrm{C}$ & 2.6 & $<0.02$ & 0.09 & $<0.005$ & 23 & $<0.05$ \\
\hline 21CC11 & $21 C C 11 C$ & 0.5 & $<0.02$ & 0.02 & $<0.005$ & 3 & $<0.05$ \\
\hline 21CC18 & 21CC18WC1 & 0.4 & $<0.02$ & 0.02 & $<0.005$ & 0.7 & $<0.05$ \\
\hline 21CC18 & 21CC18WC2 & 0.4 & $<0.02$ & 0.03 & $<0.005$ & 2.5 & $<0.05$ \\
\hline
\end{tabular}


Figures 1-8 are provided as separate Adobe Acrobat .pdf files. Clicking on a figure number will activate a link to that figure.

Figure 1-Locations of samples in the Clear Creek study area

Figure 2-South Pond, on the flood plain of Clear Creek, showing clouds of fine sediment from local tailings used to fill the pond

Figure 3-East Pond, a marshy pond occupying an abandoned channel (meander scar) on the flood plain of Clear Creek

Figure 4-Pond 3, a shallow pond occupying a meander scar on the flood plain of Clear Creek

Figure 5-Dragline dredge stacker tailings, Spring Creek

Figure 6-Dredge sluice tailings (sand, silt, and clay), overlain by stacker tailings (pebbles and cobbles), exposed in wall of Schmidt Pit, Shooting Gallery area. Bulk mercury concentrations in the various tailings layers are shown

Figure 7-Red Pond, an abandoned dredge pond fed by high-chloride springs

Figure 8-Conglomerate of the Tehama Formation, exposed in prospect tunnels beneath the Nomlaki Tuff, at Red Pond 


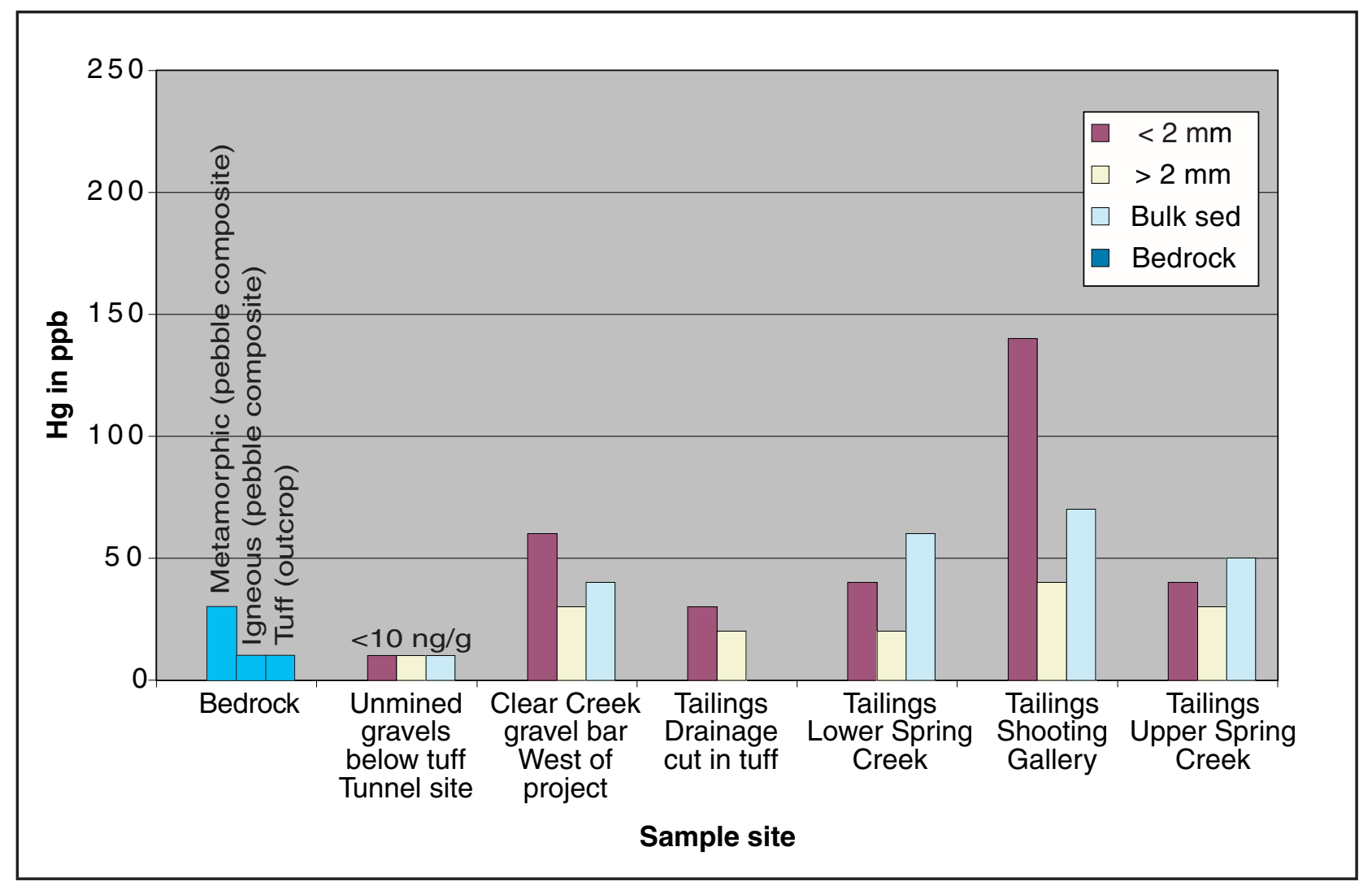

Figure 9. Distribution of mercury in bedrock, unmined conglomerate, and dredge stacker tailings and dredge sluice tailings as a function of grain size. 


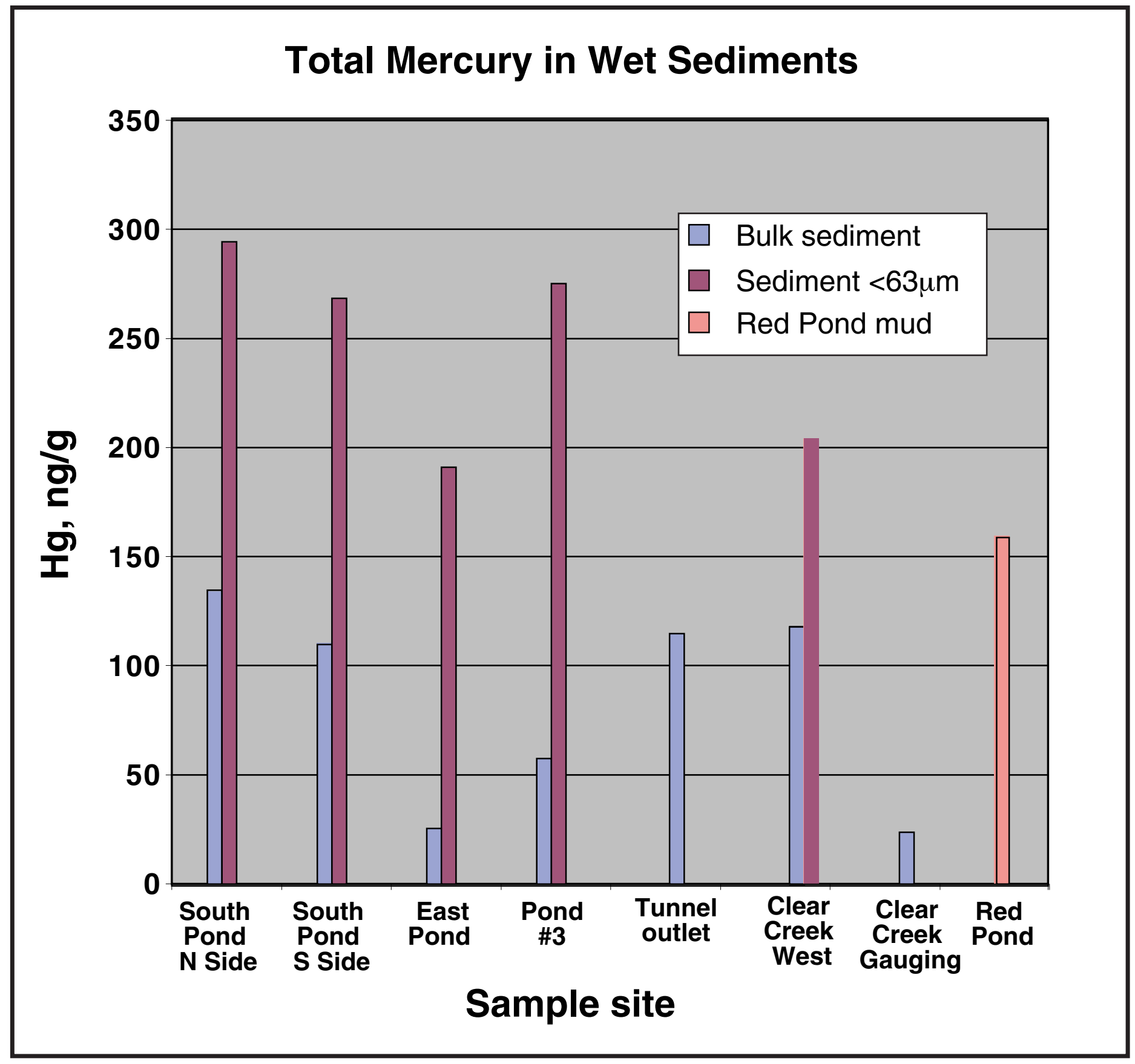

Figure 10. Mercury concentrations in sediments from ponds, hydraulic mine drainage tunnel, and Clear Creek as a function of grain size. 


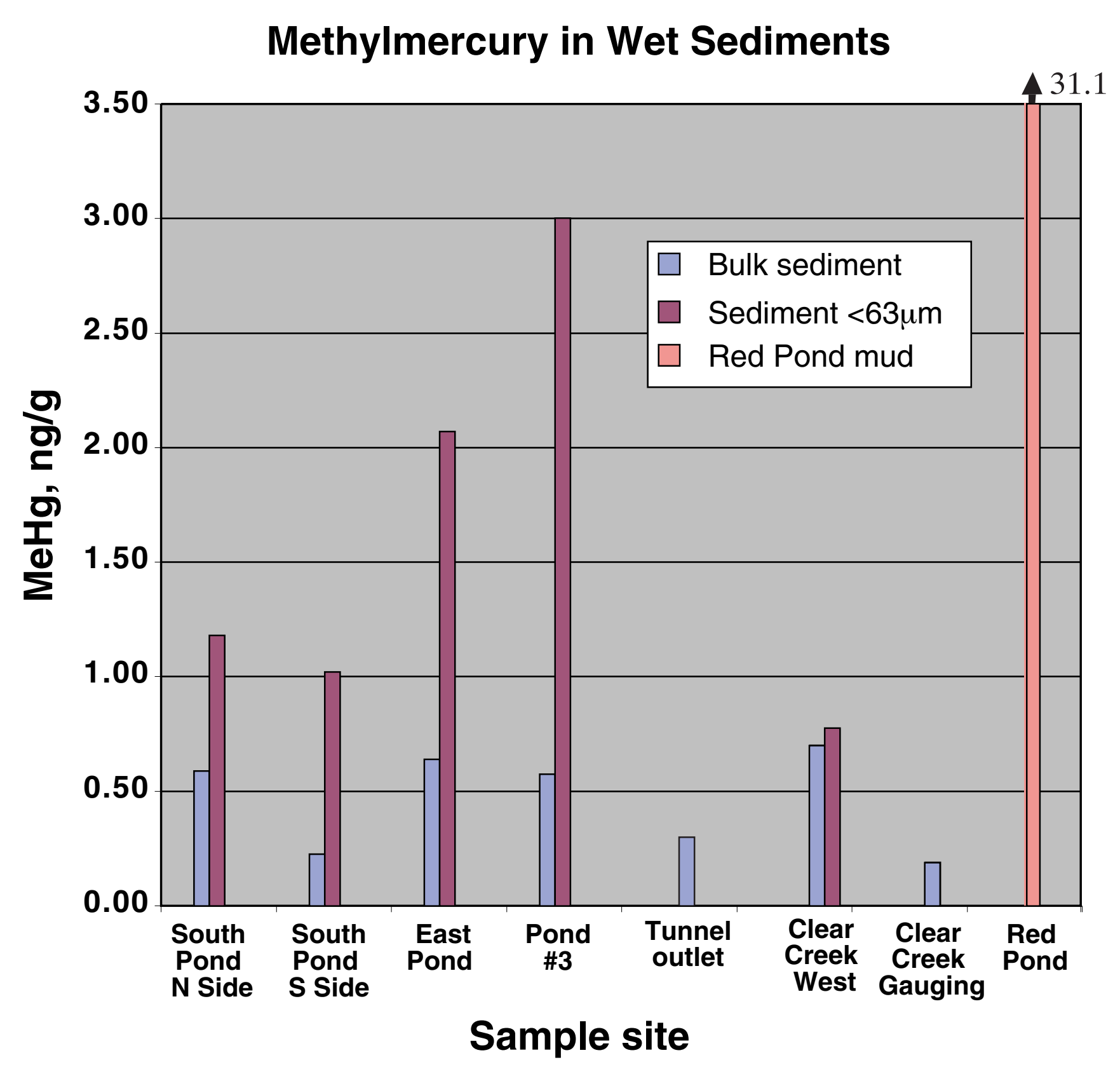

Figure 11. Metyhylmercury concentrations in sediments from ponds, hydraulic mine drainage tunnel, and Clear Creek as a function of grain size. 
$\mathrm{Hg}$, Frontier- vs. Chemex results

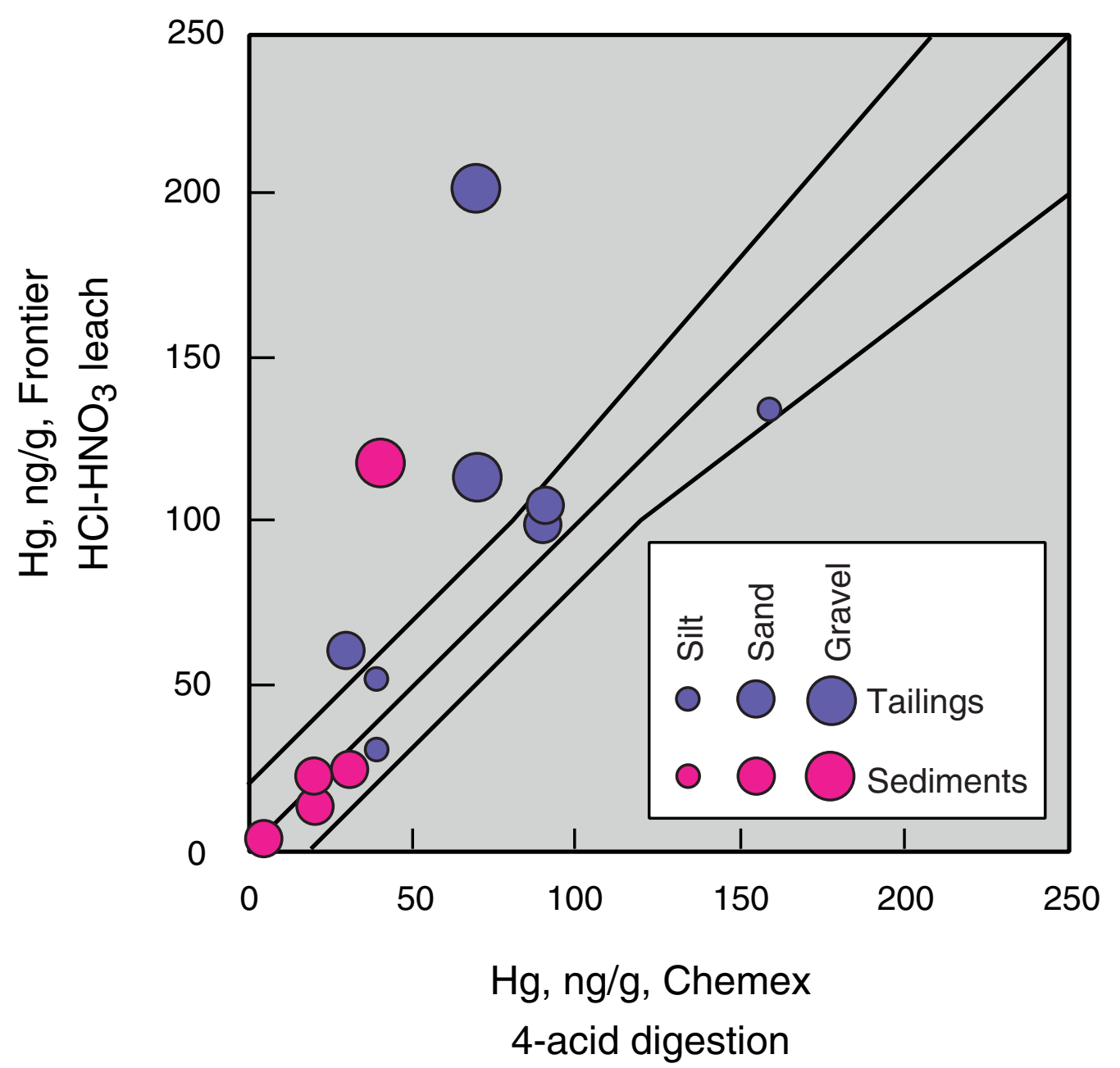

Figure 12. Concentrations of total mercury in sediments and tailings, comparison of results obtained by two different methods. 


\section{Total Mercury in Water}

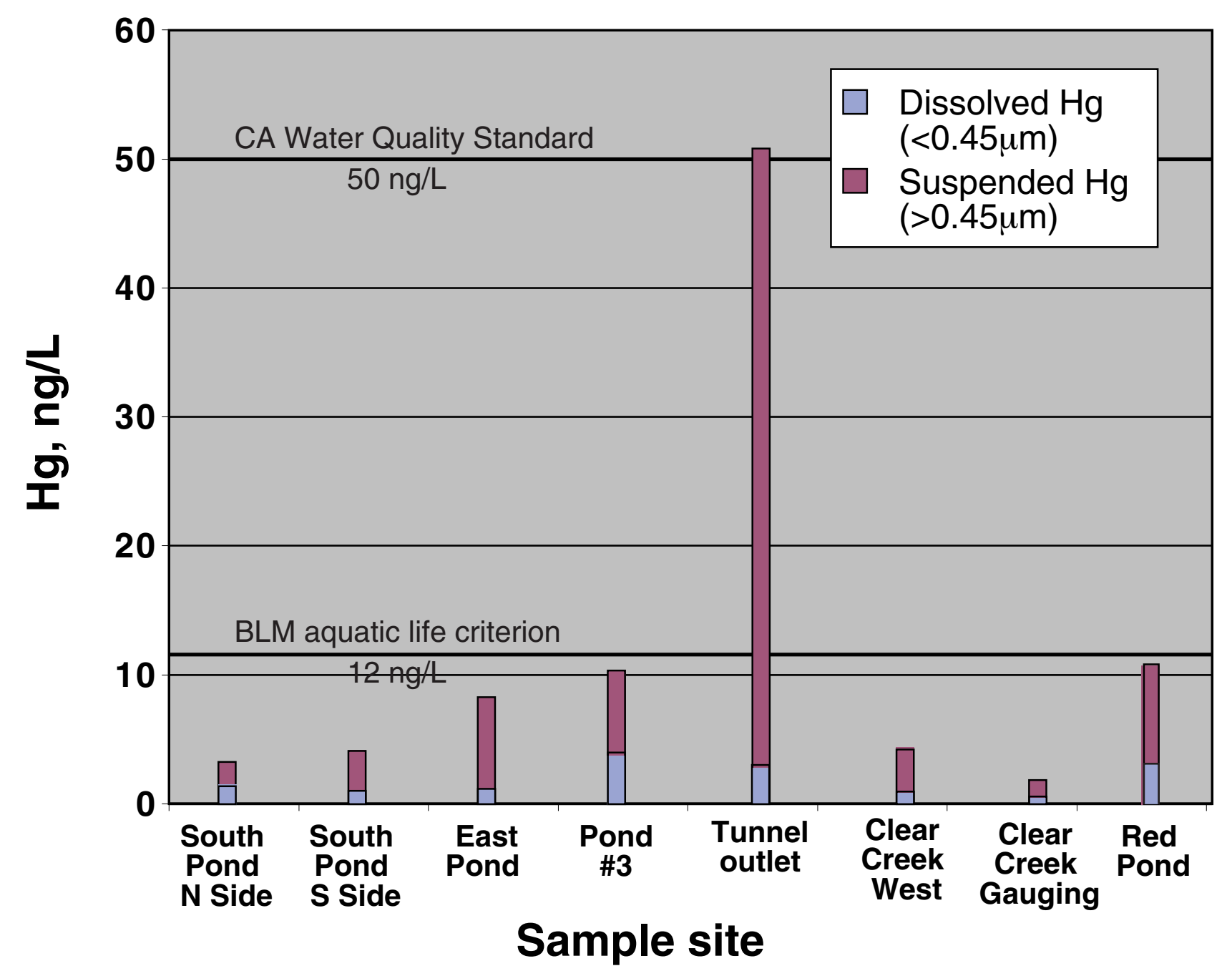

Figure 13. Mercury concentrations in waters from ponds, Clear Creek, and hydraulic mine drainage tunnel. Bars show amounts of dissolved mercury (passing $0.45 \square \mathrm{m}$ filter) and suspended mercury (difference between total and dissolved mercury). 
Methyl Hg- vs. total Hg

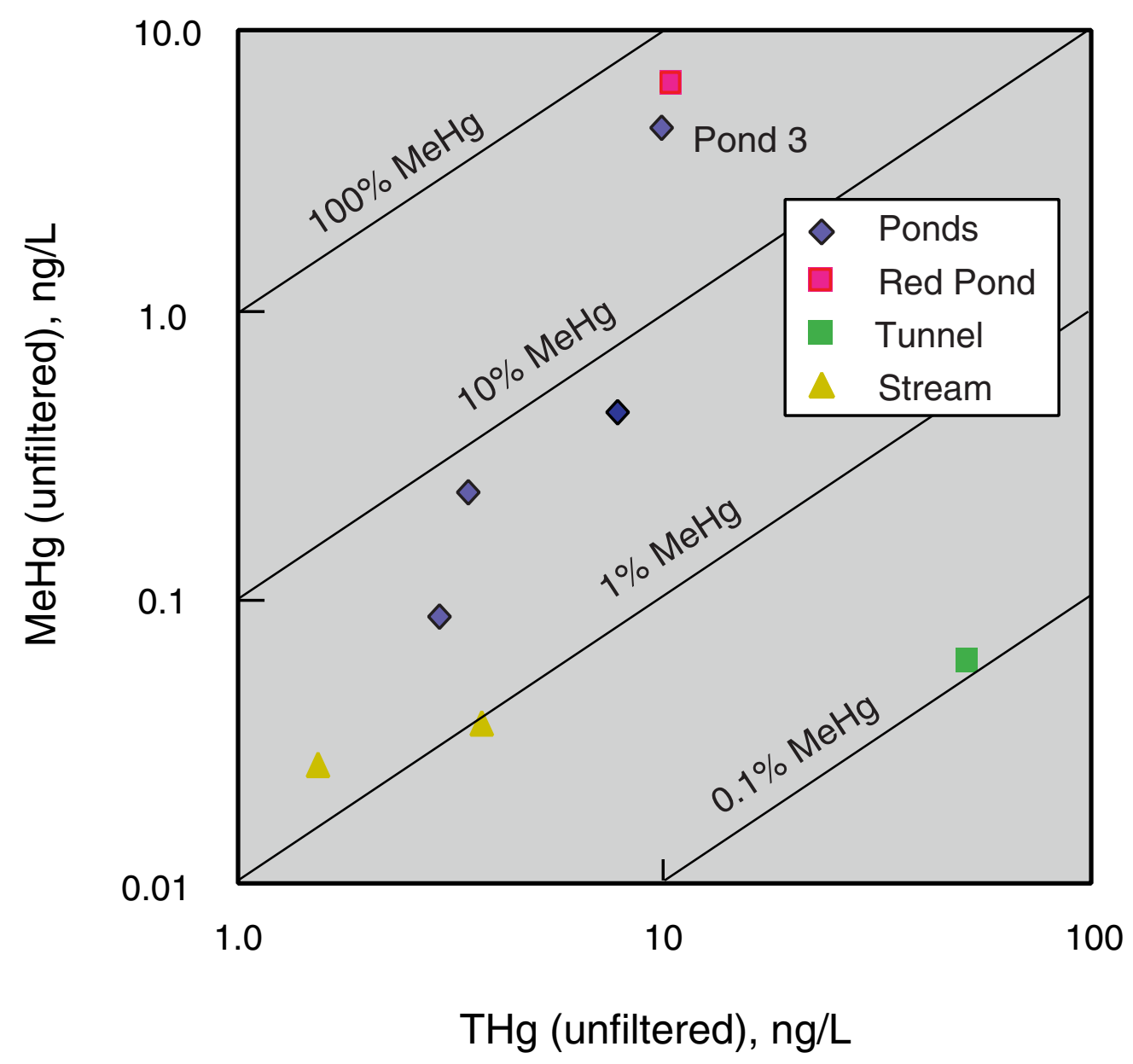

Figure 14. Methylmercury versus total mercury concentrations in waters from ponds, Clear Creek, and hydraulic mine drainage tunnel. 
Sulfate- vs. total $\mathrm{Hg}$

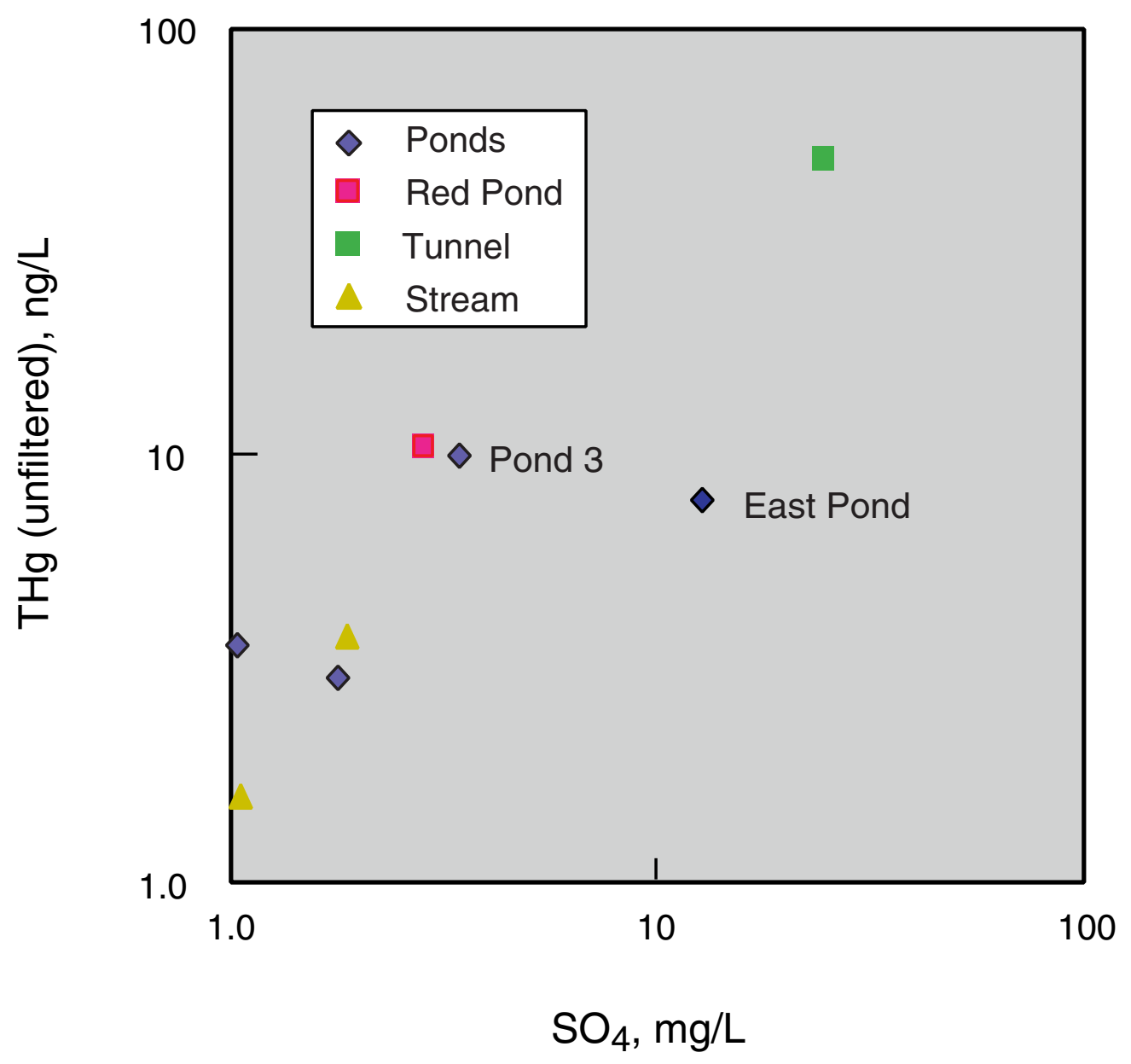

Figure 15. Sulfate versus total mercury concentrations in waters from ponds, Clear Creek, and hydraulic mine drainage tunnel. 
Total iron- vs. Hg

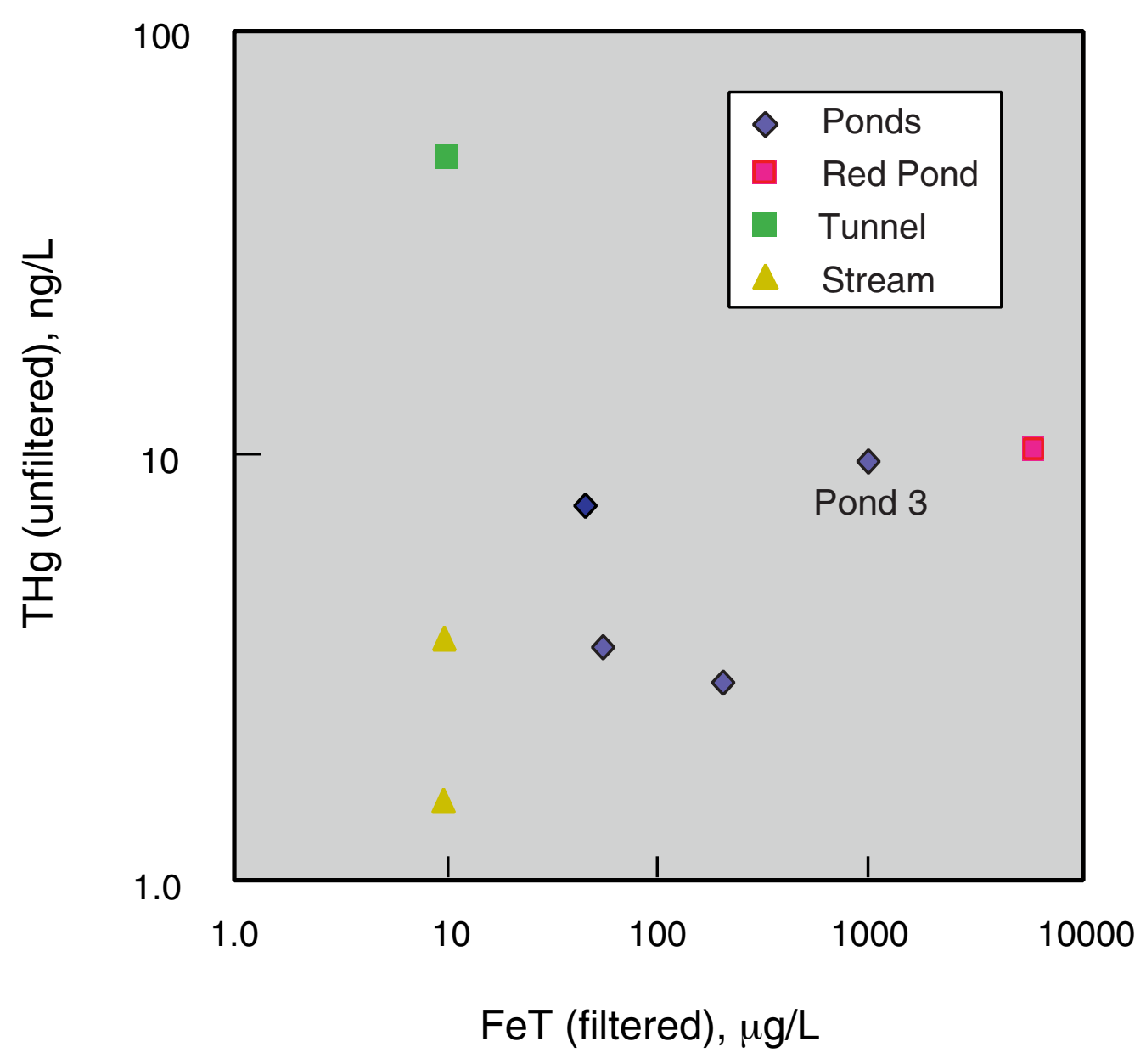

Figure 16. Total dissolved (filtered, $0.45 \square \mathrm{m}$ ) iron versus total mercury concentrations in waters from ponds, Clear Creek, and hydraulic mine drainage tunnel. 
Chloride vs. total $\mathrm{Hg}$

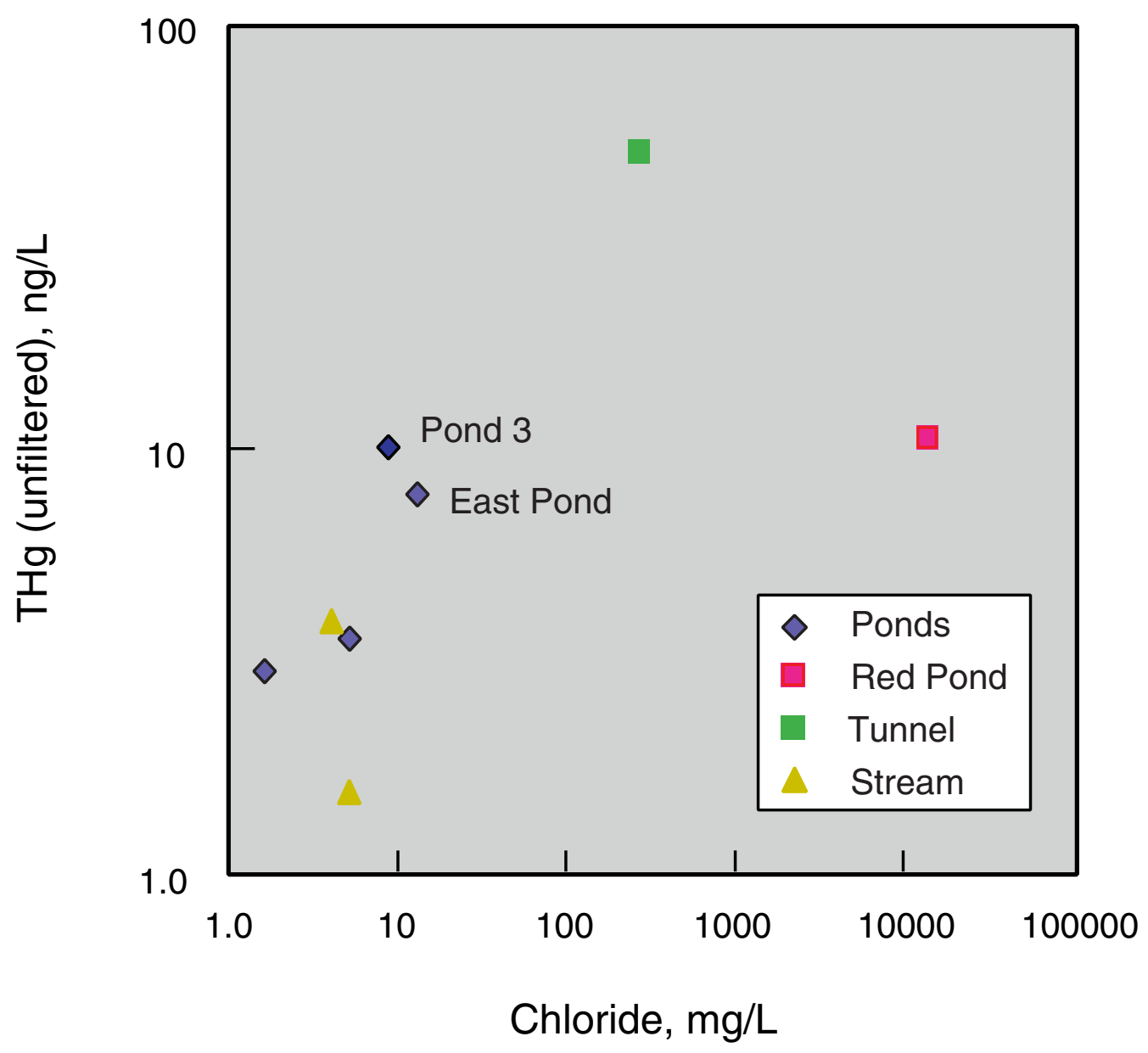

Figure 17. Chloride versus total mercury concentrations in waters from ponds, Clear Creek, and hydraulic mine drainage tunnel. 
Chloride vs. boron and lithium

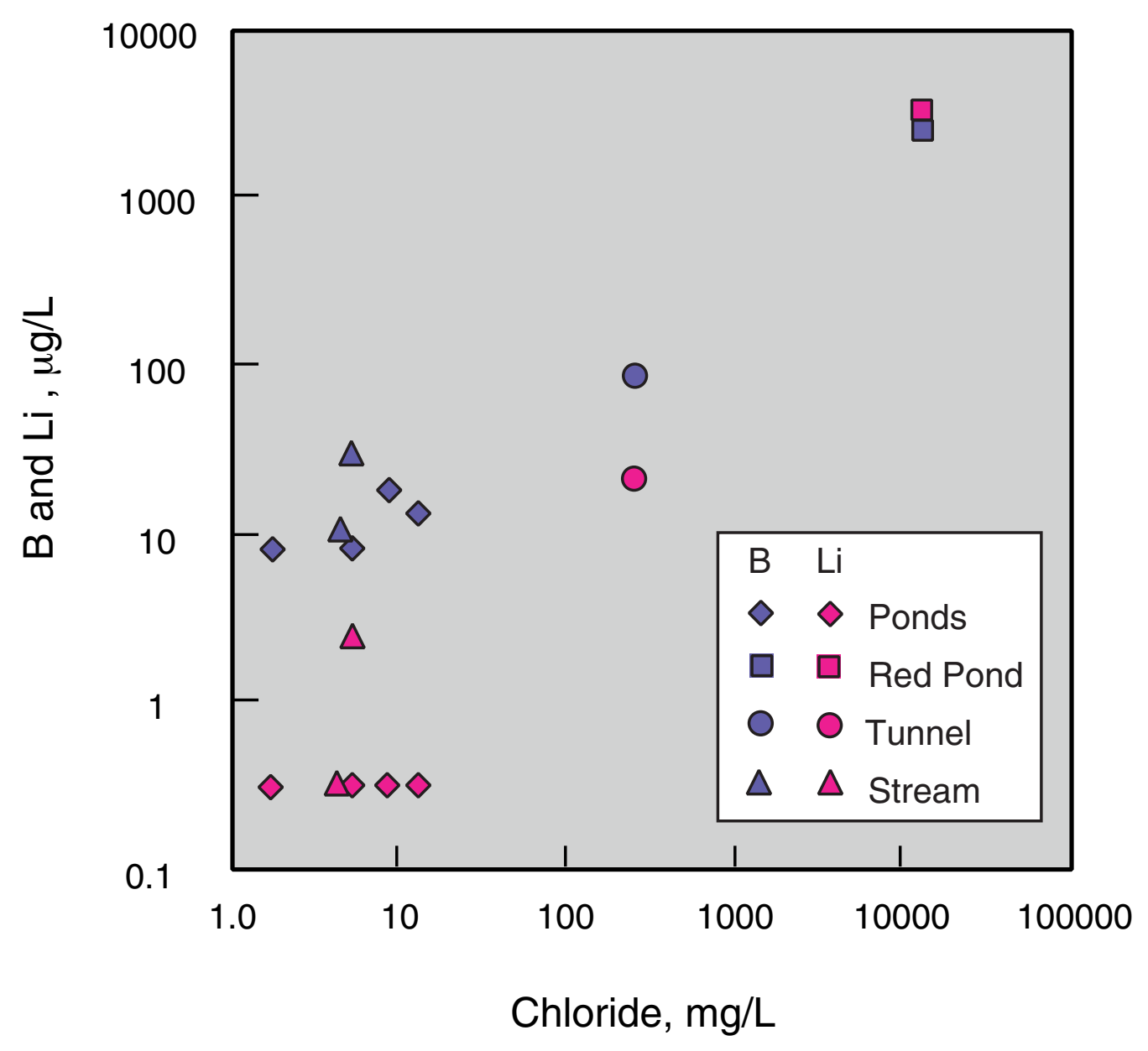

Figure 18. Chloride versus lithium and boron concentrations in waters from ponds, Clear Creek, and hydraulic mine drainage tunnel. 